No. 5

Catalogue Of Exhibits Of Malayan

Produce Sent To The Imperial

Institute, 1893 


\title{
CATALOGUE
}

\author{
EXHIBITS
}

MALAYAN PRODUCE

SENT TO

\section{The Imperial Institute}

$$
-+m:(0): \cdots+\cdots
$$

SINGAPORE

Printed at the Government Printing Ormich:

\section{3}




\section{CATALOGUE}

OF

EXHIBITS

OF

MALAYAN PRODUCE

SENT TO

The Imperial Institute

$-+\infty:(0): \infty+\infty$

SINGAPORE

Printei) at the Goversaient Printing Office

1893 



\section{A T A L O G U E \\ O F}

EXHIBITS

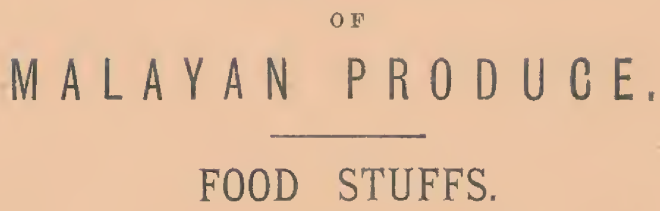

RICE.

THERE is a large quantity of rice cultivated in almost all the Native States and the Colony, but the amount is insufficient for whe needs of the Natives, and a great deal is imported, chiefly from Siam. There is no reason why the cultivation should not be extended, but the supplies from the North have been hitherto so cheap that the Natives have found it more economical to purchase imported rice than to grow it themselves. This is, hovever, very unsatisfactory, as has been recently shown by the failure of the rice crops in Siam, whereby rice rose to a high price in the Peninsula.

Rice (padi) is grown either in wet fields (sawah or bendang) or on upland farms (ladang), and there are innumerable named kinds of this grain in the Peninsula, differing slightly in size, form and colour.

\section{List of Varieties of Rice exhibIted.}

Padi Nachin Kuning, from Malacca.

"Nachin Puteh, do.

, Nachin Kerbau, do.

", Nachin Sarotin, from Negri Sembilan. This is a heavy paddy, boiling hard, one of the slowest growing kinds, taking six months to ripen. Favourite paddy for horses.

"Nachin. Hard-boiling rice, favomite with the lower classes. Negri Sembilan.

Lingeri, from Malacea.

Radin Siak, do.

Radin, from Perak; Negri Sembilan. Sweet smelling rice like Padi Undan. Takes four months to ripen.

Radin Bernam, from Perak.

, Radin Kelang, do.

"Radin Kuning, do.

"Jarum Mas, from Malacca.

"Anak Ikan, do.

"Merebau, do.

, Wangi, do.

"Larut, do. 
Padi Undan, from Negri Sembilan. A soft-boiling rice, emitting a sweet odour. Rarely planted. Prized on account of its rarity. Takes four and a half months to ripen.

Gangsa, from Negri Sembilan.

" Trong Buri, from Negri Sembilan. When cooked it becomes dry and nearly round and readily hardens. A favourite rice for feasts, and largely grown in Negri Sembilan, as a larger crop is obtained from it than from any other kind.

" Trong Dahun, from Negri Sembilan. Ordinary hard rice.

" Trong, from Perak.

"Santapan Raja, from Negri Sembilan. Boils soft and smells sweet. Favourite rice of the Malay. Yields a comparatively poor crop, but much prized for its distinct rich flavour.

" Pakang, from Negri Sembilan. Ordinary soft-boiling paddy. T'akes four and a half to five and a half months to ripen.

Sri Bumi, from Negri Sembilan. Boils soft and grows quickly. An expensive paddy to grow, as the yield is small.

Sumbut Rumut, from Negri Sembilan. Soft paddy. 'Takes four or five months to ripen.

Benang Acheh. The quickest growing paddy in Negri Sembilan; it takes only three months to ripen, and boils fairly hard. Much sought after.

Tiga Jatampoh, or Padi Jemba Bawang, from Negri Sembilan. Hard-boiling rice, inferior in yield to Trong Buri.

Sabangsa, from Negri Sembilan.

" Anak Kedah, from Perak.

Ara, do.

" Bemban, do.

" Bodor, do.

" Bunga Machang, do.

" Bunga Machang Besar, do.

" Burong (lit. bird rice), do.

" Chintek (lit. pretty rice), do.

"Hitam (black rice), do.

"Jangka, do.

" Kukubalam, do.

"Lakun, do.

"Lembut, do.

" Lembut Jarang, do.

"Lembut Merah, do.

"Malok Soson, do.

" Machang, do.

" Machang Kuning, do.

" Machang Puteh, do.

" Mayang Che Ma, do.

" Mayang Minigorek, do.

"Mayang Mulut, do.

" Orang, do. 


$\begin{array}{ccc}\text { Padi Pasan Karang, } & \text { from Perak. } \\ \text { " Puchuk Beranak, } & \text { do. } \\ \text { " Puchuk Nipa, } & \text { do. } \\ \text { " Puteh (white rice), } & \text { do. } \\ \text { " Rami, } & \text { do. } \\ \text { " Rantek, } & \text { do. } \\ \text { " Riang, } & \text { do. } \\ \text { " Sabunyi, } & \text { do. } \\ \text { " Sakai, } & \text { do. } \\ \text { " Sakapoi, } & \text { do. } \\ \text { " Samajadi, } & \text { do. } \\ \text { " Sarendah, Bohong, } & \text { do. } \\ \text { " Sarendah Krian, } & \text { do. } \\ \text { " Serai, } & \text { do. } \\ \text { " Serob, } & \text { do. } \\ \text { " Si Anteh Puteh, } & \text { do. } \\ \text { " Sibaris, } & \text { do, } \\ \text { " Sri Menjadi, } & \text { do. } \\ \text { " Sri Patani, } & \text { do. } \\ \text { " Sungkai Padang, } & \text { do. } \\ \text { " Telor Belalang (lit. } & \\ & \text { grasshopper eggs), do. } \\ \text { " Tongkat (lit. walking } & \text { do. } \\ \text { stick rice), } & \text { Tongkat Jelapang, } & \text { do. } \\ \text { " Ulat Batu Bahara, } & \text { do. } \\ & \end{array}$

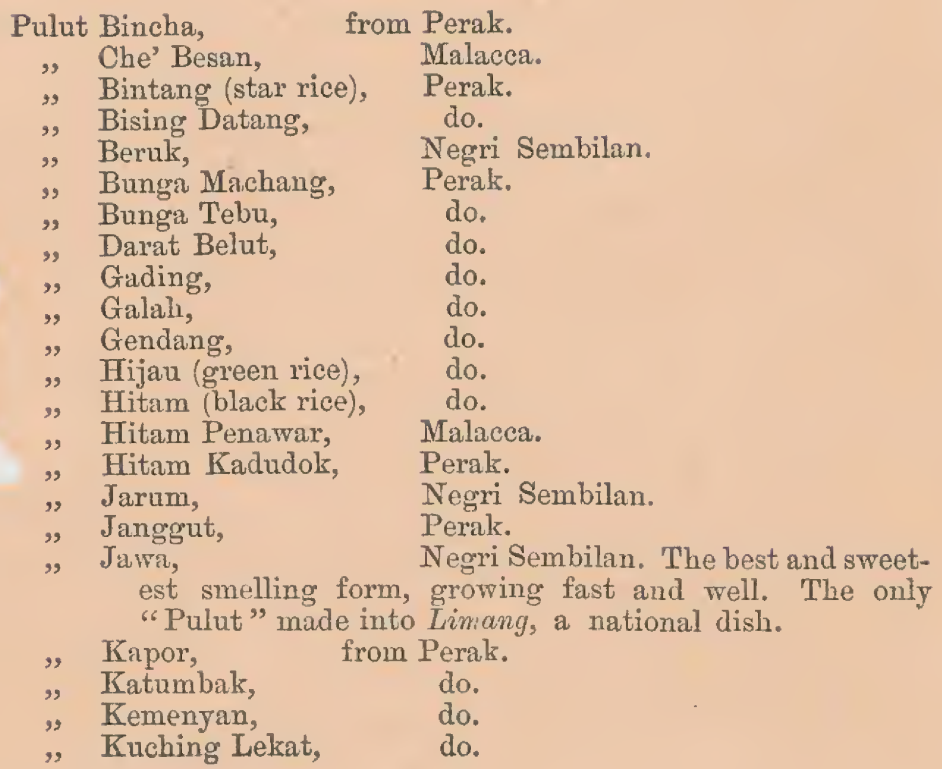


Pulut Lebai,

, Lilin,

, Lupa,

, Mengkawan,

, Merah,

, Minyak,

, Rambutan,

, Selangor,

"Tanjung,

, Pandan,

, Pipit,

, Pisang,

, Rendu,

, Samat,

, Santap Mahang,

, Selam Babi,

, Senotak Otak,

, Sepah Petri,

, Changgai Puteh,

"Soh (Sauh),

, Sntra,

"Telor,

, Tali,

" Taring Pelandok,

, Wangi, from Perak.

do.

do.

do.

Malacca.

Perak.

Negri Sembilan.

Negri Sembilan and Malacea.

Perak.

do.

do.

do.

do.

do.

do.

do.

do.

do.

Negri Sembilan.

Perak and Negri Sembilan.

Perak

do.

Malacca.

do.

\section{FLOUR.}

Sagus Rumphii and S. levis, Griff.

\section{Sagu Rembia (Mal.). Sago.}

The two kinds of sago palms are largely planted in many parts of the Peninsula. Both are inhabitants of swampy ground, such as the borders of rice-fields. The sago is prepared from the stem of the palm by pounding it and washing the pithy centre of the tree.

The flour thus produced is classed according to the size of the grains.

Spec. 470 Sago flour, Guthrie \& Co., Singapore.

$470 b$, from Perak.

$470 a$, from Malacea.

$470 \mathrm{c}$, from Sarawak, Borneo, imported by Lim Eng Keng.

471 Pearl Sago, Small, Guthrie \& Co.

472 , Medium, do.

473 " Large.

474. Native-made Sago, from Perak.

47.5 Fine-grained Sago, from Larut, Perak.

Arenga Listeri, Hemsl.

This is an elegant palm peculiar to Christmas Island, an island South of Java, and under the jurisdiction of the Straits Settlements. It produces excellent sago.

Spec. 495 Sago from Christmas Island, 
Manihot utilissima, L. (Euphorbiacece.)

Ubi Kayu (Mal.). Taproca.

Tapioca is the principal industry of Negri Sembilan, and also cultivated for export by the Chinese in most of the other States. It is grown from cuttings, and is of very easy cultivation. It is prepared in many forms.

Spec. 476 Flake Tapioca, from Negri Sembilan.

477 Small Flake, , Malacea.

478 Small Flake, $\quad$, Guthrie \& Co., Singapore.

477a Medium Flake, , Guthrie \& Co., Singapore.

476a Medium Flake, ", Comrie \& de Mornay, Pro-

4766 Large Flake, vince Wellesley.

, Comrie \& de Mornay, Pro-

$476 c$ Large Flake, vince Wellesley.

479 Small Pearl Tapioca,, Negri Sembilan.

483 Sinall Pearl Tapioca, , Malacea.

$483 a$ Medium Pearl, ,

4.94. Large Pearl,

494 a Large Pearl,

480 Coarse Pearl,

484. Seed Tapioca,

485 Bullet Tapioca,

486 Chips,

Guthrie \& Co.

, Malacca.

, Negri Sembilan.

, Negri Sembilan.

"Guthrie \& Co.

489 Siftings from Flake Tapioca,

481 Tapioca Flour, 481 a Tapioca Flour, $481 b$ Tapioca Flour, 481c Tapioca Flour, $481 d$ Tapioca Flour, 482 Tapioca Flour,

, Guthrie \& Co.

, Guthrie \& Co.

490 Tapioca Refuse. Used for feeding pigs. Dried and packed in bags. Attempts have been made to extract a spirit from this unsuccessfully. From Negri Sembilan.

491 Tapioca Skins. Rolled down for manure. From Negri Sembilan.

492 Waste water from macerating tubs. From Negri Sembilan.

493 Liquor containing the emulsion. From Negri Sembilan.

These (490 to 4.93 ) are all waste products, for which a use may possibly be found.

Dioscorea doemonum, Roxb. (Diosenreacea.)

Ubi Gadong (Mal.).

A half-wild yam, sometimes used by the Natives. It is, however, poisonous, unless it is soaked in running water for 24 howrs before eating.

Spec. 496 Ubi Gadong, dried, from Negri Sembilan. 


\section{CEREALS.}

Coix Lachryma-Jobi, L. (Graminece.)

Jilri Batu, Jelei Pulut (Mal.). Job's Tears.

Commonly to be seen in the kampongs as a weed, but not largely cultivated.

Spec. 401 Job's Tears, white, Jilei Batu, from Larut, Peral. 402 Do., dark coloured, Jilei Pulut, do. $402 a$ Do., do., husked, do.

Zea Mais, L.

$$
\text { Jagong (Mal.). Indian Corn. }
$$

Commonly cultivated, but chiefly for eating green.

Spec. 405 Indian Corn, from Perak.

404. Red variety, do.

Sorghum vulgare, Beauv.

\section{Indian Millet.}

Seldom cultivated.

Spec. 403, from Larut, Perak.

Eleusine coracana, L.

Seldom cultivated.

$$
\text { SAMbaU (Mal.). }
$$

Spec. 431, from Larut, Perak.

Pennisetum italicum, L.

$$
\text { SeKwi (Mal.). }
$$

Cultivated in Perak, Pahang, etc.

Spec. 406 Ears, from Larut, Perak. $406 a$ Seed husked.

_ from Malacea.

_ from Negri Sembilan.

Arachis hypogoea, L.

\section{PULSE.}

Kachang Tanah (Mal.). Ground-nuts.

Grown for food or oil. (See Oils.) Only cultivated on a small scale.

Spec. 43021 Ground-nuts, from Larut, Perak. $430 a$ " husked, do.

Voandzeia subterranea.

Kachang Manila (Mal.). Earth-nUts.

Seldom cultivated.

Spec. 432 Earth-nuts, from Larut, Perak. $432 \alpha$ " husked, do. 
Adenanthera pavonina, L.

Buah Saga (Mal.).

Seeds of a fine tree, used when cooked to make cakes, \&c. Raw they are said to be intoxicant.

Spec. 433 from Perak.

Phaseolus radiatus, L.

Kachang Hijau (Mal.). Green Beans.

Spec. 4.07 from Perak.

Vigna Catiang, L.

Kachang Phrut Ayam (Mal.).

Spec. 409 from Larut, Perak.

Vigna sinensis, Sav.

Kachang Panjang (Mal.). Long Beans.

Spec. 410 from Perak.

Canavalia gladiata, Roxb.

Kachang Parang (Mal.). Sword Beans.

Spec. 412 from Perak.

Var. White Sword Beans.

Spec. 411 from Larut, Perak.

Pachyrrhizus tuberosus, Benth.

Kachang Sengruang (Mal.).

Spec. 434 from Perak.

Phaseolus sp.

Kachang Dudok (Mal.). White Beans.

Spec. 408 from Larut, Perak.

Pisum sativum, L.

Chinesa Green Peas.

Spec. 413 From Shanghai, imported by Teo Guan Tai.

Red China Beans.

Spec. 414 from Swatow, imported by Teo Guan Tai.

$414 a$ from Canton.

Black China Beans.

Spec. 415 from Tientsin, imported by Teo Guan Tai.

White Beans.

Spec. 416 from Swatow, imported by Teo Guan Tai.

418 from Shanghai.

BeaN Flour.

Spec. 417 from Swatow, imported by Teo Guan Tai.

Spec. $417 a$ Vermicelli made from bean flour by the Chinese, Singapore. 


\section{VARIOUS EDIBLES.}

Nelumbium speciosum, Don. (Nympheacere.)

Teratai (Mal.).

The seeds and flour made from the rhizome are eaten by the Chinese and Malays.

Spec. 420 Lotus seeds, from Siam, imported by Teo Guan Tai.

423 Flour from rhizomes, from Swatow.

Citrullus vulgaris, L. (Cucurbitacex).

WATER-MELON.

Spec. 424 Red water-melon seeds, from China, imported by Teo Guan Tai, Singapore.

Spec. 425 Black water-melon seeds, from the same.

Peyhap Flowers.

Spec. 428 imported by Teo Guan Tai.

KIamy Siт.
Spec. 419 imported by Teo Guan Tai.

I BI.

Spec. 4.21 imported by Teo Guan Tai.

FRUITS AND PRESERVES.

Anona squamosa, L. (Anonacea.)

Custard Apple.

A Soutl American fruit much cultivated here under the name of Nona.

Spec. 4.54 preserved in spirits, from Malacca.

$A$. reticulate, $\mathrm{L}$.

Nona Kapri (Mal.). Bullock's Heart.

Spec. 453 in spirits, from Malacea.

Garcinia mangostana, L. (Guttifera). Mangosteen.

Spec. 448 from Malacea.

G. atroviridis, Griff.

\section{Asari Geludgui (Mal.).}

A very handsome fruit, chiefly dried by the Malays in slices, for eating with curry, and by no means as well known to Europeans as it should be. A very excellent preserve can be made from it.

Spec. 462 Dried Asam Gelugur, from Negri Sembilan. Lansium domesticum, Jaeq. (Meliacea.)

Langsat (Mal.).

Fruit of a fair sized tree, very popular among Europeans and Natives.

Spec. 445 in spirits, from Malacea. 
Par. Duku.

$$
\text { DUко (Mal.). }
$$

Apparently only a variety of the Langsat, differing from it in thickness of the skin and other points.

Spec. 415 Dukus in spirits, from Malacea.

Averrhoa bilimbi. (Rutac3a).

$$
\text { Belimbing (Mal.). }
$$

Fruit used chiefly in curries.

Spec. 4.1 from Malacca.

A. carambola, L.

$$
441 \text { a preservel with pine-xpples, from Negri }
$$

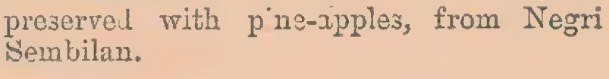

Kemeora (Ma!-).

Fruit chiefly used in tarts and preserves.

- Spec. 4.52 in spirits, from Malacca.

Triphasia trifoliata. (Rutacec).

Limad Keah (Mal.). Lime Berry.

Not often cultivated. Used in preserves.

Spec. 4.61 Preserve of lime berries with two kinds of limes, from Negri Sembilaı.

Eugenia sp. (Myrtacex).

$$
\text { Jambo Ayer Chili (Mal.). }
$$

One of the best of the rose-apples.

Spec. 4.49 from Malacca.

Psidium guava, L. (Myrtacece).

$$
\text { Janbu Biji (Mal.). Guava. }
$$

The guavas of the Malay Peninsula are inferior to those of South America.

$$
\text { Spec. } 457 \text { Guava in spirits, from Malacca. }
$$

Anacardium occidentale, L. (Anacardiacece).

Gajus also JangGus (Mal.). Cashew-nuts.

Not rarely cultivated and half wild in the Peninsula, especial'y on the sea shore.

Spec. 400 Husked cashew-nuts, from Perak.

41) 0 a Unhusked casherv-nuts, do.

4006 Cashew-nuts in spirits, from Malacca.

Bouea microphylla, Griff. (Anacardiacece).

$$
\text { Romenia (Mal.). }
$$

An acid fruit good for making tarts.

Spece 4.58 in spirits, from Mulacca. 
B. macrophylla, Girift.

Kundangan (Mal.).

A larger fruit than the last.

Spec. 458 from Negri Sembilan.

Mangifera indica, L.

Mempelam, Manged (Mal.). Mango.

The mangos of the Peninsula are very inferior.

Spec. 459. Mango in spirits, from Malacci.

M. cosia, Gritl.

Binjai (Mal.).

A poor kind of mango, much sought by the Natives. Its smell and taste are too strong for Europeans.

Spec. 460 Binjai in spirits, from Malacea.

M. foctida, Griff.

Bachang. (Mal.).

A stroncr-smelling coarse-flavoured mango, much used by the Natives.

Spec. 463 from Malacea.

Carica papuya, L. (Pussiflorea.)

Betik (Mal.). Paraw.

Cultivated everywhere. The Straits papayas are among the best in the world.

For milk (see Drugs.)

Spec. 443 Papaya in spirits, from Malacea.

443a Do. preserved, from Negri Sembilan.

$443 b$ Do. preserved by Teo Guan Tai, Singapore.

Cynometra cuuliflora, Roxb. (Leguminosa.)

NaM-Nam (Mal.).

Fruit not much used.

Spec. 447. Specimen in spirits, from Malacea.

Cicca acida, Roxb. (Euphorbiacea.)

Chermela (Mal.).

Spec. 450 in spirits, from Malacca.

Achras sapota, L. (Sapotacece.)

Chiku or Sawa Manila (Mal.). Sapodrlla.

Commonly cultivated.

Spec. 456 in spirits; from Malacca.

456a preserved sapodilla by Teo Guan Tai, Singapore. 
Ananassa sativa, L. (Bromeliacece.)

Nanas (Mal.). Prne-apple.

Extensively cultivated in Singapore, where there are many acres covered with pines. Chiefly used for the tinning industry. There are several factories of tinned pines in Singapore, and large quantities of the preserved fruits are exported.

Spec. 440 Specimen of a pine in spirits, from Malacea. 440 a Tinned pines, from Chin Choon Planting Co. 44.06 Do., from Teo Guan Tai, Singapore. 441 Pine-apple jam, from Negri Sembilan.

Castanopis sumatrana, Miq. (Cupulifere.)

Berangan (Mal.). Wild Chestnuts.

There are several species of Castanopsis in the Malay Peninsula, which are very excellent eating.

Spec. 429 Chestnuts, from Perak.

Musa sapientum, L. (Musacece.)

Prsang (Mal.). Banana, Plantain.

Very many named varieties of plantain are cultivated by the Malays.

Spec. 464 Pisang Kaki tinned by Teo Guan Tai, Singapore.

$464 a$ Pisang Mas.

\section{SPICES.}

Eugenia caryophyllata, L. (Myrtacece.)

\section{Bunga Chingker. (Mal.). Cloves.}

The flower buds of a small tree cultivated in many parts of the Peninsula. The best exported cloves howerer come from Amboina and other Eastern Islands.

Spec. 525 Cloves, from Province Wellesley.

525 a Clores, from Waterlon Estate, Perak.

$525 b$ Green cloves, from Province Wellesley.

525 e Cloves, from Malacea.

$525 c$ Cloves, imported by Guthrie \& Co., Singapore.

525d Cloves, from Amboina, from Boustead \& Co.

Coriandrum sativum, L. (Umbellifero.)

Katumbar (Mal.). Cortander Seeds.

Much used by the Malays in curries. Imported into Singapore.

Spec. 528 Coriander, from Boustead \& Co., Singapore.

Cuminum cyminum, L. (Umbellifero.)

\section{Cumin Seeds.}

Imported. Used in curries.

Spec. 529 from Boustead \& Co., Singapore. 
Carum carvi, L. (Tmbelliferce.)

Jintan (Mal.). Caraway Seeds.

lmportad in $\circ$ Sinzajors.

S) zc. 530 from Bustad \& Co.

('apsicum annurum, L. (Solanacea.)

Lada Merah (Mal.). Cirili.

Commonly cultivated here.

Spec 532 Chilies, from Malacca.

$532 a$ Chilies, imported by Boustead \& Co., Sin-

O. baccatum, Roxb. gapore.

Chili Padi (Mal.). Bird's Pepper. Spec. 534 from Larut, Perak.

Myristica moschata L. (Myristicacece.)

PaLa (Mial.). Nutmegs and Mace.

Formerly there were very large plintations of nutmegs in Sinapore, but owing to a disease the cultivation lapsed. Still, however, a considerable quantity of nutmeg's are cultivated in the Peninsula, an 1 many wre exported not only from the peninsular cultivatinus but a!so importel ones from the Moluceas. The nutmegs of Banda have the higher reputation. The largest plantation in the Peninsula is in Malacea. Mare is the aril of the nutmeg.

Spec. 526 Nutmegs, from Province Wellesley.

$$
\begin{aligned}
& 526 a \quad, \quad \text { complete witl husks and aril. } \\
& 52 \kappa b \quad \% \text { from Pengerang, Johor. } \\
& 526 c \text { " " Larut, Perak. } \\
& 52 \mathrm{Cd} \quad, \quad \text { " Bauda, imperted by Boustead \& Co. } \\
& 526 e \quad " \quad \text { imported by Guthrie \& Co. } \\
& 527 \text { Mace, from Province Wellesley. } \\
& 527 a \text { " Malicea. } \\
& 5276 \text { " "Pengerang, Johor. } \\
& 527 \mathrm{c} \quad, \quad \text { imported by Boustead \& Co. } \\
& 527 d \quad, \quad \text { from Larut, Perak. } \\
& 527 e \text { " imported by Guthrie \& Co. }
\end{aligned}
$$

Piper nigrum, L. (Piperacere.)

$$
\text { Lada (Mal.). Black Pepper. }
$$

Pepper is largely grown, chiefly by Chinese, in many parts of the Peninstila.

Spec. 522 Black Pepper, from Klang, Selangor.

$\begin{array}{lll}522 a & \text { " } & \text { Negri Sembilan. } \\ 522 b & \text { " } & \text { Muthrie \& Co., Singapore. } \\ 522 c & \text { Malikoff Estate, Province Wel- } \\ 522 d & \text { " } & \text { Maley. } \\ 522 e & \text { Malacea. }\end{array}$


$522 f$ Black Pepper, from Boustead \& Co., Singapore. $522 g$ "Government Gardens, Kuala Kangsa, Perak.

5227

$522 k$

Tapa, Batang Padang, Perak.

$522 i$

,

"

cleaned, from do. do.

9 from Gunong Pondok, Kuala Kangsa, Perak.

523 White Pepper, from Klang, Selangor.

$523 a \quad " \quad$, Negri Sembilan.

$523 b \quad$ " $\quad$ "Guthrie \& Co., Singapore.

$523 c \quad, \quad, \quad$ Malacca.

$523 d$

$523 e$

$523 f$

", T.Mackenzie, Batu Pahat, Johor.

", Boustead \& Co,

", Government Gardens, Kuala Kangsa.

Piper cubeba, L. (Piperacece.)

Cubebs.

This has recently been introduced into the Peninsula and is cultivated in Johor. It is not very easy of eultivation, but is a very valuable product.

Spec. 524 Cubebs, from Guthrie \& Co. $524 a$ from Pengerang Estate, Johor.

Cinnamomum zeylanicum, L. (Laurinece.)

\section{Kayu Manis (Mal.). Cinnamon.}

This tree grows readily and could be cultivated to a very large extent were there a large enough demand for it.

Spec. 532 from Malacea.

$532 a$ from Boustead \& Co., Singapore.

C. nitidum, Bl.

Kulit Lawang (Mal.). Indian Clove Bark.

The bark of a wild cinnamon with a very aromatic flavour. It is used as a spice, and an oil (See Oils) is extracted from it.

Spec. 538 Clove bark, from Perak.

Curcuma longa, L. (Zingiberacece.)

Kunyet (Mal.). Turmeric.

A scitamineous plant, the rhizome of which is much used in curries. Cultivated chiefly by Malays.

Spec. 535 imported rhizomes, from Boustead \& Co. 535 a from Larut. Perak.

Alpinia galanga, L. (Zingiberacece.)

Lengkuas (Mal.).

Rhizomes of this plant are used for flavouring curries.

Spec. 536 from Negri Sembilan. 
Elettaria cardamomum, L. (Zingiberaceo.)

CARDAMOMS.

Seldom cultivated and only in small quantities.

Spec. 531 Round cardamoms, from Larut, Perak.

$531 b$ Round cardamoms, husked, from Larut, Perak.

531a Long cardamoms, imported, from Boustead \& Co.

Zingiber officinalis, L. (Zingiberacece.)

Halia (Mal.). Ginger.

Not seldom grown by Natives, but never on a large scale.

Spec. 537 Ginger, from Larut, Perak.

\section{BEVERAGES.}

Thea chinensis var. assamica. (Ternstrcmiacea.)

\section{Daun Té (Mal.). Tea.}

Tea is being cultivated with great success in a few places in the Peninsula, and, as it grows easily and well here, is likely to prove one of the most important cultivations in the Peninsula. The largest estates at present are at Batu Pahat, in Johor, under the management of Mr. Turing Mackenzie, and Cicely Tea Estate in Perak, under the charge of $\mathrm{Mr}$. T. Watson. A little tea is also cultivated by Natives-Malays and Chinese.

Spec. 500 from Batu Pahat Estate, from Mr. Turing Mackenzie.

501 Pekoe, from Cicely Tea Estate, Perak.

$502 \alpha$ Souchong,

502

503 ching Hills.

from Government Gardens, Tai-

$503 a$ 2nd quality, from Tapa, Batang Padang, Perak.

$503 b$ Chinese made tea, 3rd quality.

504. Chinese tea from Foochow, imported by Teo Guan Tai.

Coffea liberica, Hiern. (Rubiacece.)

Kahwah, Kopi (Mal.). Liberian Coffee.

Liberian coffee is cultivated extensively throughout the Peninsula. It grows well in the low country, and under proper cultivation fruits well, and heavily. It is grown in almost all the provinces, by Europeans and Natives. The largest plantations are in Johor, Singapore, Sungei Ujong and Perak.

Spec. $506 p$ In cherry, Native grown from Slim, Perak. 5060 from 2,000 feet elevation, Waterloo Estate, Perak.

$506 u \quad$ in spirits, from Province Wellesley. $506 r \quad$ Native grown, from Tapa, Perak. 
Spec. 506k Parchment, Native grown, from Tapa, Perak. 506 n , from Waterloo Estate.

$507 l$ Pea berry, from Tapa, Perak.

$506 q$, from Waterloo Estate, Perak. 506 a Malacca coffee, cultivated by Tan Hun Guan. $506 b$ Johor, Batu Pahat, by Mr. Turing Mackenzie.

506 Johor, Pengerang Estate, by Mr. T. Bailey. $506 m$ Native grown at Slim, Perak.

$506 i$

$506 \mathrm{~g}$ from Province Wellesley.

$506 h$ from Negri Sembilan.

$506 t$ from Waterloo Estate, Perak.

506 s from Tapa, Perak.

$506 c$ imported coffee, from Guthrie \& Co.

$506 d$ from Timor Deli, from Guthrie \& Co.

506 e from Bali, imported by Guthrie \& Co.

$506 f$ from Palembang, Sumatra; imported by Guthrie \& Co.

Coffea arabica, L. Arabian coffee is at present cultivated only in Perak, as it requires a high elevation here for successful eultivation.

Spec. 507 Native grown, from low country.

507 a In parchment, from Waterloo Estate.

5076 Cleaned, from Waterloo Estate.

$507 c$ Peaberry, do.

$507 d$ Cherry, do.

Coffee leaves used as tea by Natives.

Spec. 505 from Perak.

Vitis carnosa, Roxb. (Ampelidece).

$$
\text { Liakon. (Mal.). }
$$

Used as tea by Natives.

Spec. 508 from Negri Sembilan.

Ilex paraguayensis, L. (Ilicinece).

$$
\text { Paraguat Tea. }
$$

Spec. 509 Sample cultivated in Botanic Gardens, Singapore. This tree grows here very well, but there is no demand for the tea.

\section{SUGAR.}

Saccharum officinarum L. (Graminea).

\section{Gula (Mal.). Cane Sugar.}

The sugar-cane is very largely cultivated for eating, and there are a few large sugar estates under European management in varims parts of the Peninsula. The most extensive of which are at Prye River, Province Wellesley, and in Lower Perak.

Spec. 510 Syrup sugar, from Prye River, Province Wellesley.

511 1st Molasses, 
Spec. 512 2nd Molasses, from Prye River, Province 519 Rum, Wellesley.

518 Milk Punch, 517 Rum Shrub, 513 Non-chemical sugar, "from Gula "Estate, Krian, Perak.

514. Chinese basket sugar,

515 Malay cane sugar, from Larut, Perak.

516 Sugar candy, from Singapore, made by Teo Guan Tai.

Arenga saccharifera, L. (Palmece.)

Kabong also Enau. Gula Matata (Mal.). Sugar Palm.

The sugar called Gula Malaka by the Malays is obtained from the sugar palm by cutting off the flower bud, and collecting the sap which exudes in joints of bamboo, the liquid is then evaporated and purified.

Spec. 520a Malay Kabong sugar, from Larut, Perak. * $520 \quad, \quad$ " , from Negri Sembilan.

Cocos nucifera, L. (Palmew.)

Coco-nut sugar made in the same way.

Spec. 521 Malay made, from Larut, Perak.

$521 a$ from Singapore, made by Teo Guan Trai.

\section{OILS, ETC,}

Cocos nucifera, L. (Palmere.)

\section{Kalapa (Mal.). Coco-NuT.}

The coco-nut is naturally very extensively cultivated in the Malay Peninsula, especially along the Coast. Much of the fruit is eaten, used in curries, etc., and a certain amount of copra is being manufactured, especially in Singapore, Province Wellesley, Pahang, etc., and also in the Cocos Islands. But little is used in the manufacture of fibre (see Fibres).

Spec. 1 a Coco-nuts from Seah Liang Seah, Singapore. $2 a$ Copra from Guthrie \& Co., Singapore.

$2 b \quad, \quad$ Province Wellesley.

$2 c$ " $"$ the Straits Settlements, McKerrow.

$2 d \quad " \quad$ Pontianak, McKerrow.

Aleurites triloba L. (Euphorbiacece.)

Buah Keras (Mal.). Candie-nuts.

The seeds of a large tree from which is extracted a large quantity of oil suited for burning and for cookery by the Natives.

Spec. 34 Seeds from Larut, Perak.

$34 a \quad, \quad$ Negri Sembilan. 
17

GAHOR-NUTS.

Gahor oil extracted from Gahor-nuts. Spec. 35 Nuts, from Perak.

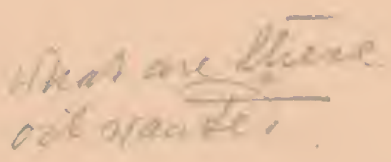

Camellia drupifera, Roxb. (Ternstroemiacea.)

Spec. 33 Oil of wild-tea berries, imported into singapore from China by Teo Guan Tai.

Plang Oil.

Plang oil is used as an external application in psoriasis, pityriasis and icthyosis by the Malays of Upper Perak.

Spec. 28 Oil, from Perak.

Andropogon nardus, L. (Graminene.)

Citronella Griass.

Spec. 37 Citronella grass, from Larut, Perak.

s. citratus, Dec.

Shrai (Mal.). Lemon Grass.

Spec. $27 a$ Oil of lemon grass, from Selama, Perak.

$27 b$ Grass.

A. muricatus, Retz.

Khus-Khus. Vetriver.

Spec. 38 Roots of khus-khus, fiom Larut, Perak.

The three grasses are well known for the strong scented oils which can be extracted from the leaves of the first and the roots of the last. Citronella and lemon grass oils ore produced, by distillation, on the Perseverance Estate at Gélang in Singapore, under Mr. Charles Allen. The oils are used for rheumatism by the Natives; and also taken internally, and are exported for soapmaking and perfumery.

Ricinus communis, L. (Euphorbiucece.)

$$
\text { JARAK (Mal.). }
$$

Castor oil is made to a small extent here, both as a lubricant and for medicine.

Spec. $17 a$ Seeds, from Perak.

176 Husks of fruit, from Negri Sembilan.

$16 a$ Castor oil, from Perak.

166 Three bottles of oil extracted by Seah Liang Seah, Singapore.

Sesamum indicum, L. (Sesamea.)

Birain (Mal.). Gixgelly. Til.

The seeds are used.as food, and oil is extracted from them in a few places.

Spec. 19a Seeds of sesamum, from Perak.

196 ," husked, from Perak,

18 ail of sesamum, from Perak. 
Spec. 4:26 Black til seed, from Siam, imported by Teo Guan Tai.

427 White til seed, from Shanghai.

Arachis hypogua, L. (Leguminosce.)

Ground-nuts are often cultivated, chiefly however as food.

Spec. 21 Ground-nuts, from Perak.

$20 n$ ()il of ground-nuts, from Perak.

ILodgronia heteroclitu, Cogn. (Cucurbitacea).

A large climbing grourd, not uncommon in Perak and Pahang. The fruit is a crrey velvety woody gourd of a flattened subglobose shape, which contains a numbrr of large oily seeds from which is extracted an oil used for rheumatisin.

Śpec. 22 Oil of Hodgsonia seeds from Perak.

$2: 3$ Seeds

Bassiu sp. (Supolucere.)

KeITOR (Mal.).

Spec, 2ta Seeds of ketior, from Larut, Perak.

24 Oil.

Licsisia sp.

\section{SURIN OIL.}

An oil made from the seeds of a species of Bassia.

Spec. 32 from Upper Perak.

\section{Y E S.}

Bixa oreliana, L. (Bixinea.)

\section{Kasumba (Mal.). Arnotro.}

The amotio plant, a mative of South America, has long been cultivated in the Malay Peninsula, and may often be found in a half-wild state far from present cultivation. The Malays use it as a dye for cloth. At the present price of the product, it would not repay cultivation, thomgh it grows rapidly and easily from seed, and fruits heavily.

$$
\begin{aligned}
& \text { Spec. } 39 \text {. from Malacca. } \\
& 39 a \text { Pods , Perak. } \\
& 396 \text { Seeds, }
\end{aligned}
$$

Garcinia pictoria, Hanb. (Guttifera.)

\section{GAMBOGE.}

This is imported from Siam in sticks, but the plant is not cultivated in the Peninsula.

Spec. 42 Siam gamboge, imported by Paterson, Simons \& Co. 
Fibraurea chloroleuca, Miers. (Menispermacec.)

Akar Kuning. (Mal.).

A strong growing liane, abundant in all the low country forests in the Peninsula. The stems are about four inches through, and climb to a great height on the jungle trees. The stem, and especially the roots, produce a bright yellow dye formerly used by the Malays for colouring cloth.

Spec. 46 Stems and roots from Malacea.

Lawsonia inermis, Hook. (Lythrariece.)

$$
\text { TnaI (Mal.). Henna. }
$$

A bush with pink or white flowers with a scent of nignonette, cultivated for the red dye used for dyeing cloth, and also for staining the nails and hair. A native of Persia, often cultivated by the Malays.

Spec. 43 Henna leaves, from Perak. $43 a \quad, \quad$, Negri Sembilan.

Ca salpinia sappan, L. (Leguminosce.)

\section{Kayu Sepang (Mal.). Sappan Wood.}

A small tree, the bark of which gives a red dye. It is a native of the Malay Peninsula, growing on the river banks. It is also commonly to be found in the villages half cultivated.

Spec. 44. Sappan wood, from Perak.

Indigofera tinctoria, L. (Leguminosce.) Auec.

$$
\text { TARUM (Mal.). Indigo. }
$$

Indigo is cultivated in Singapore, Perak and other parts of the Malay Peninsula, but never on a very large scale. The indigo is used for dyeing cloth locally, and not exported. The trade is almost exclusively in the hands of the Chinese.

Spec. $40 a$ Indigo plant, from Larut, Perak.

4.0b Dried leaves, ,

$40 \mathrm{c}$ Indigo containing much lime, from Krian.

$40 d$," without lime, from Larut.

40e , from Malacea.

Justicia sp. (?) (Acanthacece.)

A herb from which the Malays extract an indigo.

Spec. 45 from Larut, Perak.

Calamus draco, L. (Palmea.)

Jerenang (Mal.). Dragon's Blood.

This red dye is made by the Malays from the fruits of this rattan. Spec. 41 a Powdered dragon's blood, from Krian, Perak.

$41 b$ Raw dragon's blood, imported by Guthrie \& Co., Singapore.

$41 c$ Cake dragon's blood

41 Dragon's blood, from Krian, Perak." 


\section{TANNING MATERIALS.}

Of all the tanning materials produced in the Malay Peninsula, gambier holds the first place, but comparatively little is used in the Singapore tanneries, though it is very largely exported, and is one of the most important of the Straits Settlements exports. A number of barks of various trees, chiefly littoral, are used in the tanneries, some of which will probably produce valuable extracts worthy of export hence.

\section{GAIMBIER.}

Uncaria gambir, Roxb. (Rubiacea.)

An extract made by boiling the leaves of the gambier plant, an indigenous climber. The cultivation is mainly in the hands of the Chinese, who use the simplest form of apparatus. The product, in the form of an earthy-brown substance, consists of catechin and catechu tannic acid. Large quantities are exported from Singapore, being derived from the Peninsula, chiefly from Singapore, Johor and Malacca, and from the adjacent Dutch islands-Rhio, Banka, \&c.

The drug is made up in several forms, of which Block Gambier and Cube Gambier are the usual exported forms. This product is used in tanning and dyeing, and very largely in the silk trade for strengthening the silk.

Several other forms are made, chiefly by the Malays, for chewing with sirih leaves in the place of betel-nut.

Spec. 114. Block Gambier, exported by Guthrie \& Co., Singapore.

$114 a$ Block Gambier, exported by McKerrow \& Co., Singapore.

112 Cube Gambier, Gambir Dudur (Mal.), from Negri Sembilan.

$112 a$

$112 b$

$112 c$

$112 d$ ", from Guthrie \& Co.
" No. 1 (best form.) ", Malacer.
" McKerrow \& Co.

113 Finger Gambier, Gambir Paku (Mal.), from Negri Sembilan.

113a Finger Gambier, Gambir Paku (Mal.), from Negri Sembilan, used for dyeing and tanning by $\mathrm{N}$ atives.

113 Gambir Papan, used for chewing, from Negri Sembilan.

111 a Gambir Papan, from Malacca.

1116 Gambir Papan

115 Round Gambier, "Gambir Bulat, chewing gambier, from Malacca, 


\section{TAN BARKS.}

Scorodocarpus Ridleyi, King (Olacinece.)

Kшцм (Mal.).

Bark of a big tree which exhales a strong smell of onions, native of the thick jungle.

Spec. 97 Kulim bark, from Perak.

Carapa moluccana, Roxb. (Meliacece.)

$$
\text { Nireh (Mal.). }
$$

Bark of a tree growing in the mangrove swamps. Very common.

An extract of the bark is used for dysentery. (See Drugs.)

Spec. 130 Nireh bark, from Perak.

Tronanthes icosandra, Hook. (Linece.)

$$
\text { Pagar Anak Palo (Mal.). }
$$

Bark of a small tree, common in open woods. Much used for tanning.

Spec. 105 from Malacea.

Rhizophora conjugata, Wt. (Rhizophorece.)

$$
\text { BaKAU (Mal.). }
$$

One of the mangroves. The most important tan-bark here.

98 Bakau bark, from Perak.

98a " $\quad$ from Tampin, Sungei Ujong.

$98 b \quad$ " from Malacca.

98c " " from Province Wellesley.

Eugenia sp. (Myrtacece.)

\section{BARKS.}

$$
\text { Kayu Kelat (Mal.). }
$$

Spec. 93 from Perak.

E. sp.

$$
\text { SAMAK JaMru (Mal.). }
$$

Spec. 95 from Perak.

E. sp.

$$
\text { Samak Pulut (Mal.). }
$$

Spec. 99 from Perak.

$99 a$ from Negri Sembilan.

E. sp.

$$
\text { SAMAK NASI (Mal.). }
$$

Spec. 101 from Negri Sembilan.

E. sp.

$$
\text { SAMraK JAWA (Mal.). }
$$

Spec. 107 from Malacca.

Glochidion nanogynum, Hook. $f$.

Samak Serai (Mal.).

Spec. 96 from Perak. 
Calostegia Griffithii, Mast. (Malvacea.)

Punggai Bark.

Spec. 94 from Tampin, Negri Sembilan.

Ceriops Candolleana, Arn. (Rhizophorece.)

Tengah (Mal.).

Spec. 94 from Perak.

$$
\text { Batek (Mal.). }
$$

Spec. 106 from Malacea.

Morinda tinctoria, L. (Rubiacece.)

\section{Mengeudu (Mal.).}

A small tree apparently only known in cultivation. Much used in tanning. The roots and bark are the parts used.

Spec. 103 Mengkudu, from Tampin, Negri Sembilan.

Smilax barbata, Roxb. (Liliacece.)

$$
\text { Sebeheng (Mal.). }
$$

A thorny elimber, the tubers of which are used for tanning.

Spec. 103 Sebeheng root, from Malacea.

Eugenia lepidocarpa, Roxb.

$$
\text { SAMAK (Mal.). }
$$

Spec. 104 from Malacea.

\section{BETEL-NUTS.}

Areca catechu, L. (Palmea.)

\section{Pinang (Mal.). Betel-nut.}

The seeds of a palm used for chewing by the Malays, also used to a small extent in medicine. Cultivated everywhere.

Spec. 116 Betel-nuts, from Province Wellesley. $116 a \quad, \quad$ from Negri Sembilan.

\section{DAMMARS.}

The sources of some of these dammars is even at present very obscure. They are mainly classified and named in the trade by appearance and colour. A considerable quantity is found in the ground of the forests, where it has exuded from the big trees often after they have fallen, and it is quite impossible to guess from what kind of tree they have come. Much dammar is also obtained by the natives in the following way:-Large square holes are cut in the side of the tree and the bottom of the hole is scooped out so as to form a cup. A fire is lit in the hole and allowed to burn for some time. The dammar then exudes into the hole, and is collected from the cup-shaped lower part.

Canarium dichotomum, Engl. (Burseracew.)

Damar Larut (Mal.).

Spec. 66 from Perak. 
C. sp.

Spec. 74 Damar Kedondong, from Malacca.

Shorea sericea, Dyer. (Dipterocarpeas.)

An inferior dammax used for torches.

Spec. 53 Damar Batu, from Negri Sembilan.

Hopea micrantha, Hook. (?)

Damar Mata Kuching.

Obtained from the trees known as Penak and Merawan. The best form of dammar.

Spec. 55a from Negri Sembilan. 557) from Perak.

Damar Penak.

Largely used for mixing with Damar Mata Kuching.

Spec. 5la from Negri Sembilan.

$51 b$ from Perak.

Damar Penak Merah.

Spec. 61 from Perak.

DaMAR KIJAT.

An inferior dammar used for torches.

Spec. 52 from Negri Sembilan.

$52 a$ from Perak.

Hopea meranti. (?)

Damar Meranti.

An inferior dammar used for torches chiefly.

Spec. 54a from Negri Sembilan.

$54 b$ stump of a tree with dammar exuding, from Malacca.

54c from Perak.

Hopea serayah. (?)

Damiar Seraya.

Spec. 61 from Malacca.

Dammara orientalis, Lamb. (Coniferc.)

A lofty coniferous tree, usually found at about 2,000 feet high.

Spec. 60 Damar Minyak, from Malacea.

73 from Negri Sembilan.

Dammars of doubtful origin.

Damar Daging (Mal.). Rose Damimar.

Spec. 57 from Negri Sembilan. 64, " Perak.

Damar KePong.

Spec. 58 from Malacca, used for varnish. 
Damar Batang.

Used for torches.

Spec. 59 from Malacca.

Damar Kangoh.

Spec. 65 from Perak.

Damar Rengirong.

Spec. 68 from Perak.

Damar Siput.

Spec. 69 from Perak.

Damar Sistit.

Spec. 70 from Perak.

Varjous Dammars.

Spec. 796 from McKerrow \& Co., Singapore.

62 , Guthrie \& Co., Singapore.

Gum copal No.63, imported by Guthrie \& Co.

, by Paterson \& Co.

- WOOD OILS.

Dipterocarpus pterygocalyx, Roxb. (Dipterocarpece.)

Minyak Krueng.

Spec. 75 from Perak.

from Malacca.

$3 a$ Raw wood oil, from Guthrie \& Co.

D. sp.

Krunang Dadek.

Spec. 76 from Perak.

Chinese Paxnt Gum, only used to mix black and red paints.

Spec. 77 imported by Teo Guan Tai, Singapore.

Bolued Chinese VArnish.

Spec. 78 from Teo Guan Tai.

Raw Chinese Varnish.

Spec. 79 from Teo Guan Tai.

Chinese Paint Dryer, used with the above.

Spec. 79 a from Teo Guan Tai. 


\section{GUTTAS AND RUBBERS.}

Dichopsis Gutta. (Sapotacea.)

Getah Taban (Mal.). Gutta Percira.

The inost valuable of the Gutta Perchas.

Spec. 350 from Negri Sembilan.

$350 a$, Selangor.

$350 b$, Pahang, from Paterson, Simons \& Co.

360 Getah Merah, from Guthrie \& Co.

353 Bolongan Gutta, from Paterson, Simons \& Co.

354. Banjer Gutta,

355 Kotaringin Gutta, ,

352 Kelang White Gutta, from Guthrie \& Co.

Payenu Learii, Barek. (Sapotacece.)

Getam Sunder. (Mal.).

An inferior class of Gutta.

Spec. 351 from Selangor.

Willughbein cortacerer (Apocynacece.)

Getah Gerip (Mal.). Getah Grip-grip.

Rubber extracted from a lofty jungle climber.

Spec. 356 from Chabau, Malacea.

356 a Klang, Selangor.

W. culutis, Roxb. (Apocynacert).

Getain Jelir, Getah Ujol. (Mal.).

Spec. 357 Gutta from Tampin, Negri Sembilan.

Urceola torulosa, Bentl. (Apocynacea.)

Getali Serapong, Surapat. (Mal.).

Spec. 35la from Paterson, Simons \& Co. 3516, Guthrie \& Co.

Dyera costukata, Hook. (Apocynacea.)

Getah Susu. (Mal.).

Spec. 358 from Borneo, Paterson, Simons \& Co.

Artocarpus Nunsteri, King. (Urticacece.)

Getah Teríp. (Mal.).

A Gutta chiefly used for catching birds, and for adulterating other kinds of guttas.

Spec. 359 from Negri Sembilan.

\section{DRUGS, ETC.}

Erythroxylon coca, H. B. K. (Linece.)

Coca.

Coca has been introduced into the Straits Settlements, and apparently grows very well.

Spec. 5 to Cocil leatres, from Perak. 
Cassia fistula, L. (Leguminosce.)

Rarely cultivated, but sometimes planted as an ornamental tree.

Spec. 541. Pods of Cassia fistula, from Perak.

Derris elliptica, Roxb. (Leguminosce.)

Tuba (Mal.).

A creeping shrub often cultivated for its root, which is used for poisoning fish. The roots are dug up fresh, pounded and mixed with lime, and a solution of this poured into the river intoxicates the fish so that they are easily caught.

Spec. 548: Tuba root, from Larut, Perak.

Eurycoma latifolia, Roxb. (Simarubece.)

Penawar Pahit. Bidara Pahit. (Mal.).

A small erect shrub or tree producing from its bark and root a powerful bitter much in repute among the Natives. Common in Singapore, Malacca, Pahang, etc.

Spec. 13. Oil of Penawar Pait, from Tan Hun Guan, Malacca.

Piper chaba, L. (Piperacece.)

Chabai (Mal.).

A small erect stoloniferous pepper about six inches high, with dark green leaves, and white flowers. Abundant in villages and waste grounds.

Spec. 15 a medicinal oil of Chaba, from Tan Hun Guan, Malacca.

Blumea balsamifera, L. (Composito.)

\section{Sembong (Mal.).}

A strongly scented camphoraceous plant attaining a height of six feet, very common in open waste ground all over the Peninsula, especially near villages. By distillation of the leaves, a bright green oil is extracted, with a strong odour of camphor. From it is prepared the Ngai Camphor of China, a very highly priced camphor. Medicinal properties are also attributed to it, it being used for rheumatism and cold.

Spec. 9 Sembong oil, from Tan Hun Guan, Malacea.

Melaleuca leucodendron. (Myrtacece.)

Kayu Puteh, Gelay (Mal.). Cajeput.

A large tree growing in wet open country in Malacca and other parts of the Peninsula. The well-known kayu puteh (or as the word has been altered "cajeput") oil is extracted from the eaves of the tree. The best oil comes from Bourou, where the 
plant appears slightly distinct from the Peninsula form, and has been called Melaleuca minor. The thick papery bark of the tree is also used for caulking boats.

Spec. 14a Kayu puteb oil, from Tan Hun Guan, Malacca. 146 ", "from Guthrie \& Co., Singapore.

\section{Abo Putra.}

A medicinal oil made from the roots of this plant.

Spec. 8 Oil, from Tan Hun Guan, Malacca.

Tengkok Biawak.

A medicinal oil.

Spec. 10 from Tan Hun Guan, Malacca.

Penawar Hitam.

Spec. 11 Oil from this plant, from Tan Hun Guan, Lindera sp. (Taurinece.) Malacca.

Perawas. (Mal.).

Spec. 12 Oil of Perawas, from Tan Hun Guan, Malacca. Cinnamomum zeylanicum. (Laurinece.)

\section{Cinnamon Oir.}

An oil extracted from cinnamon, used medicinally by the Chinese. (See Spices.)

Spec. 5 from Malacca, made by Tan Hun Guan.

Cinnamomum nitidum, Bl. (Laurinece.)

Kulit Lawang, Medang Lawang (Mal.). Indian Clove Bark.

A small tree from the bark of which an oil is extracted and used medicinally. The bark itself is also used as a spice. (See Spices.)

Spec. $5 a$ Oil extracted from the bark, from Perak.

$$
5 b
$$
leaves, ,

5c Leaves" of the tree, from Perak.

$5 d$ Bark.

4 Oil, from Malacca, made by Tan Hun Guan.

$$
\text { Bara URAT OIL. }
$$

A medicinal oil made from the root of this plant.

Spec. from Tan Hun Guan, Malacca.

Pogostemon patchouli, L. (Labiatce.)

$$
\text { Niram (Mal.). Patchouli. }
$$

Patchouli is cultivated to a considerable extent inLower Perak, and in smaller quantities elsewhere. Owing to its easy culture and preparation, and to the high price it at present commands, it is a very paying crop. The plant is grown from cuttings, which are planted in newly cleared ground, where it rapidly in- 
creases. The leaves are yathered and ronglily dried.

Spec. 29 a Oil of patchouli, from Selama, Perak.

30 Leaves of patchouli, from Selama. Perak.

Urena lobata, L. (Malvacece.)

\section{Perpulut (Mal.).}

A common weed, the leaves of which are used to adulterate patchouli.

Spec. 31 Perpulut leaves, from Perak.

Ocimumbasilicum, Retz. (Labiatce.)

$$
\text { Ruкu-Ruke (Mal.). }
$$

A sweet-scented herb often cultivated by the Malays as medicine, and also used to ardulterate patchouli.

Spec. 3la Ruku-Ruku leaves, from Perak.

Carapa molucerana, Roxb. (Meliacerr.)

\section{Nrreh (Mal.).}

An extract of the bark of this is used for dysentery. The extract is made with rectified spirits of wine, and evaporated. (See Tan Barks.) It has a great reputation.

Spec. 546 Extract of Nireh bark, from Singapore.

Jatropha curcas, L. (Euphorbiacece.)

Jarak Blanda (Mal.). Purging Nuts.

Often cultivated, and used as a medicine.

Spec. 542 Purging nuts, from Larut, Perak.

$$
542 a \quad, \quad \text { husked } 5 \text {," } 542 b \text { rom Sri Menanti, N̈egri Sembilan. }
$$

Apostasia nuda, Lind. (Orchidere.)

Has a reputation as a medicine among the Malays.

Spec. 545 from Malacea.

Sphorococcus lichenoides Agardh. (Algae.)

$$
\text { AGAR-AGar (Mal.). }
$$

A sea-weed boiled to a clear jelly, of great reputation among the Malays. Collected on the shores of Singapore, Muar, ete.

Spec. 544 Agar-Agar, from Billiton, imported by Lim Eng Keng, Singapore.

Cassia alata, Roxb. (Leguminosre)

$$
\text { GelengGaje (Mal.). }
$$

Leaves of a shrub used for skin diseases, especially valuable in Dhobie-itch (Tinea tonsurans). Intermally taken the leaves are purgative.

Specimen from Singapore. 


\section{INCENSE.}

Styrax benzoin, I. (Styracea.)

Kemenyax (Mal.). Gum Benjamin, Benzoin.

The tree producing this gum-resin occurs in the forests of the Malay Peninsula, from Singapore northwards. It is a tall, slender tree, with grey bark and leaves, dull green above and white beneath. The gum benjamin is obtained either by simply cutting the tree, or by cutting a hole in the stem and lighting a fire in it, when the gum exudes into the hole and is collected. The gum obtained from Siam and Sumatra are said to be derived from a different species of tree, but of this we have no certain information. It is used for making incense.

Spec. $86 a$ Black benzoin, from Negri Sembilan.

86 White benzoin ", Malacca.
85 ",
83 Derak.
82 Do., Tampin, Negri Sembilan.
84 Siamese, from Paterson, Simons \& Co., Singa-
pore.
80 Sumatra, from Padang, from Guthrie \& Co.
81 Do., from Palembang, from Guthrie \& Co.

Aquilaria malaccensis, Hook. (Thymeleacece.)

Gafaru (Mal.). Lign Aloes.

A large tree widely scattered throughout the Malay Peninsula occurring in the bigger jungles. The heart-wood of the old trees is the part used. It has a great reputation as an incense.

It is generally collected by the aborigines and sold to the Malays. Only certain trees contain the product, and the collectors know which are good by the knotty appearance of the stem.

Spec. 87 Gaharu wood, from Sri Menanti.

$\begin{array}{llll}88 & \text { Do., } & \text { " Tampin. } \\ 89,91 & \text { Do., } & \text { Batang Padang, Perak. } \\ 90 & \text { Do., } & \text { ", }\end{array}$

\section{TOBACCO.}

Nicotiana tabacum, L. (Solanọcea.)

$$
\text { Tомвак (Mal.). }
$$

Spec. 372 from Kuala Kangsa, Perak.

Tobacco has as yet not been cultivated to any extent in the Malay Peninsula, and indeed when tried has not proved rery successful. The Malays have planted it in Singapore and Perak at different times in small quantities.

\section{BIAK LEAVES.}

Nauclea sp. (Rubiacea.) Spec. 371 from Perak.

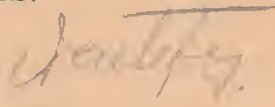


These leaves are used by the Malays of Perak in place of opium. Their properties are not known.

\section{TEXTILES. \\ FIBRES.}

Gossypium arboreum, L. (Malvaceœ.)

\section{Tree-Conton.}

Cotton is seldom cultivated in the Peninsula. Attempts have been made to grow it for profit, in Singapore, Perak and elsewhere: and it is probable that much more might be done with it, as good qualities have been produced.

Spec. 141 a Pods, from Larut, Perak.

142 Cleaned cotton, from Larut, Perak.

Gossypium herbaceum, L. (Malvaceo.)

Short staple cotton.

Spec. 140 from Larut, Perak.

Eriodendron anfractuosum, (Malvacece.)

Kарок (Mal.). Sirk Cotron.

A common tree planted and half wild all over the Peninsula. The cotton is used for stuffing pillows.

Spec. 142 Sill cotton, from Larut, Perak.

$142 a$,,$\quad$ cleaned, from do.

Hibiscus esculentus, L. (Malvacece.)

\section{Bendé (Mal.). OKRA.}

A stiff tall herb, with large yellow flowers with a maroon centre. Cultivated chiefly for its edible seed pods. Produces a good fibre, but is rarely cultivated for this purpose.

Spec. $126 a$ Fibre from the stems, from Larut, Perak.

126 Fibre from the branches, do.

Corchorus olitorius, L. (Tiliacece)

\section{JUTE.}

Could probably be grown here with some amount of success, but has not as yet been under cultivation.

Spec. 130 Fibre, from Larut, Perak.

Hibiscus titiaceus, L. (Malvacere.)

$$
\text { WARU or BARU Mal.). }
$$

A common sea-shore tree, usually of no great size, the bast of which produces a fibre used by the Natives.

Spec. 131 Bast, from Larut, Perak.

$131 b$ Bast, from Negri Sembilan.

131c Bast, from do.

$131 a$ String made of the bast, from Larut, Perak. 
Boehmeria nivea, Hook. (Urticacere.)

China Grass. Ramie Hemp.

A stiff herb cultivated as a fibre plant. The fibre is used by the Malays to make twine for nets, fishing-lines, \&e. Seldom cultivated in the Peninsula.

Spec. 123a Fibre of China Grass, from Larut, Perak. 123 Bast of the same, from - do.

Antiaris toxicaria, L. (Urticacex.)

\section{IтоH (Mal.). Upas Tree.}

A lofty tree with stiff horizontal branches, widely scattered over the Malay Peninsula. This is best known from its violently poisonous milk, which when injeeted into the blood has a strong action on the circulation and also on the intestines, producing death in a few minutes. The poison is used by the wild tribes for poisoning their arrows, and from the bast a cloth and twine is made.

Spec. 134 Bark of Ipoh, from Selama, Perak. $134 a$ Bast of the same.

Artocarpus Kunstleri, King. (Urticacece.)

\section{Getah Terap (Mal.).}

A big noble tree with wide spreading branches and large leaves lobed when young and entire when adult. Common throughout the Peninsula.

The bast forms a coarse cloth and twine, the milk is viscid and is used for birdlime to eateh pigeons. (See Guttas.)

Spec. 139 Bast, from Negri Sembilan. $139 a$ Rope, from Selangor.

Musa sapientum, L. (Musacer.)

Pisang (Mil.). Plantain, Banana.

The plantain is usually cultivated for the fruit, but a fairly useful fibre may be obtained from it.

Spec. 127 Banana fibre, from Larut, Perak.

Musa sp.

\section{Pisang Hutan (Mal.). Wrld Plantain.}

There are several wild plantains in the Peninsula, from which fibre has been prepared. It is not, however, as valuable as Manila hemp. The wild plantains grow in great abundance in Perak, Selangor, Sungei Ujong, Pahang and other provinces, and large quantities of fibre could be obtained.

Spec. 128 Fibre of wild plantain, from Larut, Perak. $128 a$

from Negri Sembilan. 
Musa textilis, L.

\section{Manila Hemp.}

Is as yet not cultivated for profit in the Peninsula, although it grows readily and well.

Spec. from Botanic Gardens, Singapore.

Ananassa sativa, L. (Bromeliacece.)

Nĕnas (Mal.). Pine-Apple.

The pine-apple is extensively cultivated for its fruit in Singapore (see Fruits), and the fibre might be preparer in quantity as the plant is of easy growth. The pines suited for fruit, however, are not suited for the fibre industry, as they are too short. Attempts have been made to extract the fibre in several places, but have not proved very satisfactory, owing to the difficulty of procuring suitable machinery.

Spec. 132 from Larut, Perak.

132 a from Negri Sembilan.

Yucea gloriosa, L. (Liliacea.)

A good fibre plant, as yet not cultivated to any extent.

Spec. 129 Fibre, from Larut, Perak.

Furcrea cubensis, Kth. (Amaryllidece)

Mauritides Hemp.

A large aloe-like plant commonly spread over the cultivated districts of the Peninsula, propagating itself rapidly by bulbils formed in the inflorescence. Very easy of cultivation, and of rapid growth. There are a few plantations, at Pulau Battam, an island lying to the south of Singapore, and elsewhere, where the plant is cultivated and prepared for export, but the want of a satisfactory cleaning: machine prevents any rapid development of this industry.

Spec. 137 Fibre, from Negri Sembilan.

Arenga saccharifera, L. (Palmacece.)

Kabong or Ĕnau (Mal.). Sugar Palm.

A large palm with a comparatively short, thick stem attaining a height of upwards of forty feet, with very large leaves of a dark green colour above and white beneath. It is commonly cultivated in the villages, but is apparently not indigenous. (See Sugars.)

It affords a strong, black fibre produced at the base of the leaf stalks, which is used for making a very strong black rope commonly known as Tali Ijuk. The rope is especially valued because it does not rot in water or when exposed to weather. It is used in thatching, for tying on the ridge-pieces.

Spec. 117 Rope, from Negri Sembilan.

$117 a$

Malacca.

$117 b$

Negri Sembilan.

117c Rope, from Peralk.

$117 d$ Fibre.

117 e Rope, from Selangor: 
Spec. 164 "Bitah" a screen used in fishing made from this palm, from Malacea.

Arenga Westerhoutii, Griff. (Palmacea.)

Langkap (Mal.).

A handsome palm occurring in damp jungles in Malacea, Perak, etc. It attains a height of about forty feet, with a grey stem, smooth, except for the rings of growtl. It produces a fibre much like that of A. saccharifera, Lab. A kind of Jew's Harp, called genggong, is made of this palm.

Spec. 135 Fibre of Langkap, from Larut, Perak.

Arenga (?)

Kabona Hutan (Mal.).

Produces a fibre like that of $A$. saccharifera.

Spee. 144 Fibre of Kabong Hutan, from Larut, Perak. Areca catechu, L. (Palma.)

The husks of the betel-nut $(q . v$. $)$ are a waste product from the betel-nut plantations, where this palm is cultivated for its seed. It does not appear to have been ever put to any use as yet, but might be utilized in paper making, etc. The spathes are used for making buckets, etc., or wrappings.

Spec. 136 Husks of betel-nut, from Larut, Perak.

$136 b$ Broken do.,

136 a Fibre, cleaned partly,

131 Areca-nut spathes, from Negri S"embilan.

Gleichenia linearis, Burm. (Filices.)

$$
\text { RESAM (Mal.). }
$$

An exceedingly abundant fern on the edges of forests, and in open country, from the stems of which is prepared a strong fibre used for ornamenting the handles of krisses, etc. It is, however, troublesome and tedious to extract it, whence it is not much used. The stems are also used for pens.

Spec, 119 Resam fibre, from Negri Sembilan.

193 a Stems of Resam,

193 Pens of Resam,

\section{THATCHES, MATS, \&c.}

The native houses are thatched and often walled with leaves of different plants. The best of these are those of the sago palmNipah and Mengluang-but when these are unprocurable, the other kinds of leaves here mentioned are used. It is possible that some of these leares might be found available for paper-making.

Actinodaphne sp. (Laurinece.)

$$
\text { GELUGUR GaJAH (Mal.). }
$$

Large hard textured leaves used for thatching.

Spec. 156 Leaves, from Malacca. 156a Attaps, from Malacca.

Agrostistachys filipendula! Hook. (Euphortiacece). 


\section{Julong-Julong (Mal.).}

A shrub with large leaves, used for thateh and for wrapping opium, ete. Common in dry jungles.

Spec. 1.57 Leaves, from Malacea.

$15 \% a$ Attaps,

Nipa fruticans, L. (Palmacece.)

$$
\text { Nipair (Mal.). }
$$

A common palm growing in saline mud near the sea, or in tidal rivers, with stout creeping rhizomes and large erect leaves. The leaves are used for making thatch, and for cigarette papers by the Malays. Wine is made from the fruit.

Spec. 158a Attaps of Nipah leaves, from Province Wellesley.

15:3 Cigarette papers (Dam Roko), from Negri Sembilan.

Zalace sp. (Palmasere.)

SAlAK (Mal.).

A stemless palm growing in wet forest, with large spinuous leaves, used for thatching. There are five or six species in the jungle of the Peninsula.

Spec. 155 Leaves, from Malacca.

155 a Attaps,

Sagus Kenigii, Griff. (Palmacea.)

$$
\text { - Rembia (Mal.). }
$$

The leares of the sago palm make the most durable thatch, and the pith of the midrib forms an excellent substitute for cork for insect boxes, etc.

Spec. 153 Rembia leaves, from Malacea. 15 are Attaps.

159 Pith of leaf midrib, prepared, from Singapore.

Eugeirsona triste, Roxb. (Palmacea.)

\section{BERTAM (MIal.).}

A stemless palm with very spiny leares, abundant in many places throughout the Peninsula, where it grows in thick jungle. The leaves are used to make attaps (thatch), and the midribs of the large leaves to make the screens commonly known as chicks. The latter form one of the industries of Penang.

Spec. 50a Leaves and attaps, from Malacca. 163 Chicks, from Province Wellesley.

Licuala spinosa, Griff. (Palmacere.)

$$
\text { Daun Patas (Mal.). }
$$

A common palm growing in tufts about eight or ten feet high in open country, the leaves of which are sometimes used as thatch.

Spec. 152 Leaves, from Malacca.

152a Attaps, from Malacca. 
Pandanus furcatus, Roxb. (Pandanacece)
MengKUANG (Mal.). Screw-PINe.

The biggest species of the genus in the Malay Peninsula attains the height of forty feet, with a stout stem branched at the top, when adult. It is abundant in low, damp forests all over the Peninsula. The leaves, which attain a length of twelve feet and are four inches broad, are the valued part of the plant, and are used for making kajangs or covers for boats, bullockcarts, houses, etc. The leaves of the young plants are cut, and the curved thorns on the keel and edges removed with a knife, and are then dried and cut into suitable lengths, for making kajangs. They are fastened together with split rattans. Mengkuang leaves are also used for making hats, baskets, etc., and a fibre can be extracted from them.
Spec. 125 Mengkuang leaf, from Perak.
151 Kajangs, from Selangor.
168 Rice baskets, from Singapore.
172 Chinese hats, from Malacca.
173 Covers for curries, from Negri Sembilan.
175 Baskets, from Pringgit, Malacca.

Pandanus odoratissimus, Roxb. (Pandanece.)

\section{Paxdan Darat (Mal.). Shore Screw-pine.}

A common screw pine occurring on the sandy coasts, about fifteen or twenty feet tall, or less. Much branched, the leares narrower and shorter than those of $P$. furcatus, Roxb., so as to be more suitable for mats and finer baskets, \&c.

Spec. 122 Leaves of pandan, from Perak.

160 Sleeping mats, from Negri Sembilan.

161 Do., from Negri Sembilan.

$160 a$ Do., from Province Wellesley.

$160 b$ Do, from Malacea.

166 Baskets of pandan leaf, from Malacca.

171 Bags of pandan leaf, from Negri Sembilan.

Pandanus sp. (Pandanece.)

Pandan laut (Mal.). Sea Screw-pine.

A very similar plant to the preceding, but with thinner and longer leaves.

Spec. 162 Mats of Pandan Laut, from Negri Sembilan.

Lepironia mucronata, Rich. (Cyperacees.)

A rush about five feet in height, used in mat-making, generally met with in wet spots near the mangrove swamps. Local, but abundant when met with. Singapore and Malacea.

Spec. Rush, from Malacca. 
Imperata cylindrica, Cyr. (Graminece.)

LALANG (Mal.).

An exceedingly abundant grass often covering acres of ground, and occurring throughont the Peninsulu. It is of little use and is considered to be most injurious to cultivation, being supposed to impoverish the soil and being very troublesome to eradicate. The leaves are employed as thatch, and the rhizomes are used by the Chinese as a medicine, and exported to China for the purpose. At one time there was a manufactory of beer from the roots in Singapore, but this has ceased to exist. Attempts have been made to nse it for paper-making, but withont success.

spece. 154 Drifl grass, from Mulaces.

15 ta Thath, from Malacca.

Scirpus grossus, Roxb. (Cyperacece).

$$
\text { Menerong (Mal.). }
$$

A rush about four or five feet tall, growing in rice-fields a zd ditches. After the rice harvest is over this rush comes up in great quantities, and is cut down and dried to make mats, baskets, bags, \&c.

Spec. 120, 120a. The rush as gathered, and the same prepared for use, from Larut, Perak.

Fimbristylis diphylla, Vahl. (Cyperacece.)

Rumput Purun Batu (Mal.).

A very common sedge in dry places, attaining the height of about a foot, used in making mats, bags, \&c.

Spec. 121 The rush, from Larut, Perak.

167 Rice basket, from Singapore.

Scirpus mucronatus, L. (Cyperacece.)

\section{Kuмbah (Mal.).}

A common rush in ponds and ditches throughout the Peninsula, used in mat-making.

Spec. 124 Kumbah plant, from Larut, Perak. Prepared do.

\section{RATTANS.}

The rattans, which are largely exported from Singapore, are the stems of the long climbing palms belonging to the genera $K$ orthalsia, Plectocomia and Calamus, while under the names of Rotan Tikus and Rotan Bini, Flagellaria indica is included as a Rotan by the Malays. The various species have all received local Malay names, but of many the scientific name is not yet known. The rattans are often brought into town by Malays, who have received them from the Sakais, who have collected them in the jungles of the interior, and though the different kinds are distinguishable when cleaned, yet it is impossible in that state to identify them 
in all the larger damp jungles of the Peninsula, often forming almost impenetrable thickets. By the aid of their long-hooked flagella, and the thorns on the midrib of the leaves, they climb to the tops of the high trees.

When collected, suitable ones are selected and cut with a parang or chopper, and the leaves having been cut off, the stem is beaten with a thick stick so as to loosen the thorny bark, which is cleaned off, and the rattan is then coiled up for convenience of carriage. On arrival at Singapore they are straightened, and cleaned by washing, and cut into leagths of a suitable size. They are put to a great number of uses, and many articles are made from them in Singapore, such as baskets, chairs, flower-pot stands, tables, mattings, cradles, and the like. Some are used as walling sticks, and others only for tying. A large quantity are also exported to America and Europe and manufactured there. Only certain kinds are used for each purpose, some being suitable for one use and some for another. They are used either whole, or split with in curious knife made for the purpose.

Specimens of articles made partially or wholly of rattans are:-

176 Rattan baskets, from Malacca.

180 Baskets of round rattan, ",

181 ", of split rattan, ,

175 Tray made of rattan and bamboo, from Malacea.

145 Rope made of twisted rattans, from Selangor.

Plectocomia elongata, Griff.

$$
\text { Rotan Dahan (Mal.). }
$$

A very stout and lofty rattan, the thickest of all the rattans. Used as split rattan only.

Spec. 212 from Malacca. $212 a$, , Perak.

Korthalsia scaphigera, Mart.

\section{Rotan Semut (Mal.). Ant Rattan.}

This rattan is infested by a peculiar species of ant which makes its nest in the swollen bases of the leaf stalks, hence its name. It is a very much sought kind.

$$
\begin{aligned}
& \text { Spec. 224 from Perak. } \\
& 224 a \text { from Chabau, Malacca. }
\end{aligned}
$$

Calamus javensis, Bl.

Rotan Sempi, Rotan Lilin (Mal.).

Spec. 217 from Chabau, Malacea $217 a$, Perak.

C. insignis, Griff.

Rotan Batu (Mal.). Stone Rattax.

Spec, 219 from Chabau and Jus, Malacca. 
C. leptopus, Griff.

- Rotan Chinchin (Mal.). Ring Rattan.

Spec. 209 from Chabau, Malacca.

C. ornatus, Griff.

Rotan Sega Badak (Mal.).

Spec. 215 from Malacea.

c. geminiflorus, Griff.

Rotan Tunggul (Mal.).

Spec. 214 from Malacea.

$214 a$, Perak.

$214 b$ sticks made from this species, from Negri Sembilan.

C. sp.

C. sp.

Rotan Bintang (Mal.). Star Rattan.

Spec. 300 from Larut, Perak.

Rotan Tawar (Mal.).

C. sp.

Spec. 301 from Larut, Perak.

Rotan Pandan (Mal.).

Spec. 302 from Larut, Perak.

C. sp.

Rotan Mantang (Mal.).

C. sp.

Spec. 308 from Larut, Perak.

Rotan Perawai (Mal.).

C. sp.

Spec. 304 from Larnt, Perak.

Rotan Dahan Tikus (Mal.).

Spec. 306 from Larut, Perak.

C. grifndis, Griff.

\section{Rotak Semambu (Mal.). Malacca Cane.}

This abundant rattan produces the well-known Malacea cane, but common as the plant is, there are but few canes nowadays obtained from the Peninsula. Sumatra supplies a large quantity. The value of a Malacea cane depends on its colour, texture and smoothness, and upon the distance between the joints.

Spec. 206a from Larut, Perak. $206 b$ from Negri Sembilan.

306 Imported canes, Stiven \& Co. 
C. Draco, L.

Rotan Jerenang (Mal.). Dragon's-blood Rattan.

A plant more sought for, for more the red colouring matter of its fruits than for its stem. (See Dyes.)

Spec. 216 from Malacea.

Spæc. $216 x$ from Lurut, Perak.

C. angustifolius, Griff.

Rotan GĔTA (Mal.).

Spec. 208 from Malacca.

C. acanthopis, Griff.

Rotan Kertong (Mal.).

Spec. 210 from Malacca.

C. hystrix, Griff.

Rotan Sabut (Mal.).

C. sp.

Spec. 231 from Larut, Perak.

Spee. 207 from Malacea.

305 , Larut, Perak.

C. longipes, Griff.

Rotan Dudur (Mal.).

Spec. 297 from Perak.

C. sp.

Rotan Relang (Mal.).

Spec. 211 from Malacca.

C. sp.

$$
\text { Rotan Udang (Mal.). }
$$

Spec. 213 from Malacea.

$213 a$ from Larut, Perak.

C. sp.

Rotan Sega (Mal.).

Spec. 218 from Malacca.

C. sp.

Rotan Gigi Ulak (Mal.). Lit., Snake's Tooth Rattan.

C. sp.

Spec. 220 from Larut, Perak.

$$
\text { Rotan Kertas (Mal.). }
$$

C. sp.

Spec. 221 from Larut, Perak.

Rotan Sega Bate (Mal.).

Spec. 222 from Larut, Perak.

$222 \alpha$ from Tan Hun Guan, Singapore. 
C. sp.

$$
\text { Rotan Sega Pasur (Mal.). }
$$

Spec. 230 from Larut, P'erak.

C. sp.

$$
\text { Rotan Serbal (Mal.). }
$$

Spec. 232 from Larut, Perak.

C. sp.

$$
\text { Rotan Haliban (Mal.). }
$$

Spec. 233 from Larut, Perak.

C. sp.

$$
\text { Rotan Kembone (Mal.). }
$$

Spec. 2:34 from Malacea.

C. sp.

$$
\text { Rotan Kasum (Mal.). }
$$

Spec. 296 from Larut, Perak.

C. sp.

$$
\text { Rotan Laras (Mal.). }
$$

Spec. 298 from Larut, Perak.

C. sp.

$$
\text { Rotan Manau (Mal.). }
$$

Spec. 299 from Perak.

C. sp.

$$
203 \text { imported by Stiven \& Co. }
$$

$$
\text { Rotan Sega Mas (Mal.). }
$$

Spec. 223 from Larut, Perak.

C. sp.

Rotan Mas (Mal.). Lit., Golden Rattan. Spec. 223 from Larut, Perak.

C. sp.

$$
\text { Rotan Haliban Tikus (Mal.). }
$$

Spec. 226 from Larut, Perak.

C. sp.

$$
\text { Rotan Mayang (Mal.). }
$$

Spec. 227 from Perak.

$$
\text { C. sp. }
$$

$$
\text { Ro'tan Kikir (Mal.). }
$$

Spec. 228 from Larut, Perak.

C. sp.

$$
\text { Rotan Semut Galah. }
$$

Spec. 229 from Larut, Perak.

C. sp.

Rotan Tiga Sagi (Mal.). Three-sided Cank. Spec. 307 from Larut, Perak. 
List of Canes under Importers' Names, frou Struen \& Co., IMPORTERs, Singapore.

Trice Canes, Billiton Canes, Rainting,

Chermety Canes, Banjer Canes, Kota Pakia Rotans, Chambee Loontee, Bulangan Passir, Pulau Laut Passir, Kelantan Segar, Belah Segar, Pahang Segar, Bulangan Segar, Sandakan Segar, Fadang Segar, เ'elawan Segar, Hoon Peng Segar, Sarawak Kenalat. Teckwak, Indragiri, Kubu,

Kayong Loontie, Sandakan Loontie, Tangnarnoo Loontie, Batawee Loontie, Hun Peng Loontie, Kelantan Loontie, Kotia Palembang Loontie, Bilak Loontie, Palembang Loontie, Padang Loontie, Penang Loontie, Kotia Passir, Tambang',

Siam,

Tana Puteh,

Booyu,

Sancolalang, Jeelie,

Coomie,

Siak,

Bentawan,

Ludikay,

Pelawan,

Sarawak Monturoo,

Padang Sarawak,

Passir Pakia, Hin Low Strait Rattan, Kamaniang Strait,
Spec. No. $-200,207$.

, 201

, 202

,204

205

,23อ

236

237

244

, 238

, 239

, 245

" 240

" 258

" 262

") 256

" 251

" 240

241

242

245

, 248

285

287

288

, 289

290

291

" 292

" 298

" 294

" 295

" 250

" 251

" 252

255

257

260

"261

,264

265

266

284

286

258

"2 259

" 263

" 267

" 268 
Loontie Strait,

Kayong Strait,

Kelantan Strait,

White Strait,

Indragiri Strait,

Sarawak Strait,

Sumbak Strait,

Padang Strait,

Pontianak Strait,

Munturoo Strait,

Balam Strait,

Kubu Strait,

Batu Strait,

Bugis Strait,

Goruntalo Strait

$\begin{array}{cc}\text { Spec. } & 269 \\ \text { " } & 279 \\ , & 271 \\ , & 272 \\ , & 273 \\ , & 274 \\ \text { " } & 275 \\ \text { " } & 276 \\ \text { " } & 277 \\ \text { " } & 278 \\ \text { " } & 289 \\ \text { " } & 281 \\ \text {, } & 282 \\ & 283\end{array}$

\section{STICKS AND BAMBOOS.}

Drymophloeus singaporianus, Becc. KerIntre.

296 Stems of a small palm abundant in the jungles much sought for making walking sticks, Singapore.

Licuala sp. (Palmoe.)

Spec. 297 Penang Lawyer, Singapore.

298 Rattanis, various, for walking sticks, \&c., Singapore.

299 Various other sticks, Singapore.

Dendrocalamus strictus. (Gramineo.)

Male Bamboo.

Spec. $299 a$ used for spear-handles, cultirated in Singapore.

VARIOUS BamboOs.

Ara Batu. (Mal.).

Spec. 321 from Negri Sembilan.

Buluh Arar. (Mal.).

Spec. 322 from Negri Sembilan.

Buluh Anak Babi. (Mal.).

Spec. 323 from Negri Sembilan. 
Buldh Kampong (Mal.).

Spec. 324 from Negri Sembilan.

Butuh Gading (Mal.).

Spec. 325 from Negri Sembilan.

Buluh Tezor (Mal.)

Spec. 326 from Negri Sembilan.

Pinanga malayana, Mart. (Palmaceee.)

\section{Pinang Burong. (Mal.).}

Sticks of this palm, Negri Sembilan.

úncosperma horrida, Mart. (Palmacese.)

$$
\text { BAYAS (Mal.). }
$$

Spec. 332 Stick of the wood of this palm, from Negri Sembilan.

Baccaurea parviflora, Hook. (Euphorbiacece).

$$
\text { Setambon (Mal.). }
$$

Spec. 333 from Negri Sembilan.

Murraya exotica.

$$
\text { Kamuning (Mal.). }
$$

An ornamental wood, much used for sheaths and bandles of krisses.

Spec. 334 from Negri Sembilan.

Arenga saccharifera, Lab. (Palmacece)

Enad. (Mal.).

Spec. 335 Stick made from the wood of this tree, Negri Sembilan.

Myristica sp. (Myristicacece.)

Penaga Lrlin. (Mal.).

Spec. 338 Stick of this wood, from Negri Sembilan.

Penah Bunga. (Mal.).

Spec. 336 from Negri Sembilan.

387 ,

do. 
 \\ A L LUVIAL TIN MINING.}

\section{DISTRICT OF SELAMA, PERAK.}

Spec. 1 Wash-dirt form mine on Larut Road.

2 Tin-sand fro:n do.

3 Wash-rirt fr' $m$ Pawang Ah Kin's mine.

4. Tin-sar:d fro'n do.

5 Wash-ilirt f om Ah Gun's mine.

6 Tin-isand from do.

7 Tin-sand from Relau.

8 Tin-sax d from Ong' Un's mine.

9 Tin-sand from Chin Ah Sue Kim's mine.

10 Coarse tin from do.

11 Tin-sand trom Lu dh Chin's mine.

12 Tin-sand from Sue Ah Kim's mine.

13 Coarse tin from Lu Ah Chin's mine.

\section{DISTRICT OF LARUT, PERAK.}

14. Tin-sand from mine near Sungei Partin, Blanda Mabok.

15 Coarse tin from Blanda Mabok.

16 Tin-sand froin do.

17 Wash-dirt from Khu Thean Tek's mine at $\mathbf{K a -}$ munting.

18 Tin-sand from Khu Thean Tek's mine at Kamunting.

19 Wash-dirt from Capt. Ah Kwi'smineat Kamunting.

20 Tin-sand from do.

21 Wash-dirt from Capt. Ah Kwi's mine at Jenah, Kamunting.

22 Tin-sand from do.

23 Wash-dirt from Sam Yam's mine on the Hills at Jenah.

24. Coarse tin from

do.

25 Wash-ilirt from Cheak Then Keng's mine at Gugup Hill.

26 Tin-sand from do.

27 Wash-dirt from Kong Fung Who Kongsi, Capt. Ah Kwi's mine at Gugup, Kamunting.

28 Tin-sand from do.

29 Coarse tin from Waterfall Hill, about 2,000 feet above sea level.

30 Wash-dirt from Li Pi's working on Maxwell's Hill.

31 Tin-sand from

do.

32 Wash-dirt from Wah Hup Kongsi, Sandhurst Tin Mining Co., Batu Togoh, 
Spec, 33 Tin-sand from Wah Hup Kongsi, Sandhurst Tin Mining Co., Batu Togoh.

34. Wash-dirt from Yeng Won Kongsi, Sandhurst Tin Mining Co.'s mine at Batu Togoh.

35 Tin-sand from Yeng Won Kongsi, Sandhurst Tin Mining Co.'s mine at Batu Togoh.

36 Wash-dirt from Yew Lung Kongsi, Sandhurst Tin Mining Co.'s mine at Batu Togoh.

37 Tin-sand from Yew Lung Kongsi, Sandhurst Tin Mining Co.'s mine at Batu Togoh.

38 Wash-dirt from Sum Sin Kongsi, Sandhurst Tin Mining Co.'s mine at Batu Togoh.

39 Tin-sand from Sum Sin Kongsi, Sandhurst Tin Mining Co.'s mine at Batu Togoh.

40 Wash-dirt from $\mathrm{Hu}$ Ngin Kongsi, Sandhurst Tin Mining Co., Batu Togoh.

41 Tin-sand from $\mathrm{Hn}$ Ngin Kongsi, Sandhurst Tin Mining Co., Batu Togoh.

42 Wash-dirt from Sandhurst Tin Mining Co.'s mine at Klian Pau, Tupai.

4. Tin-sand from Sandhurst Tin Mining Co.'s mine at Klian Pau, Tupai.

44 Wash-dirt from Li Pi's mine at Klian Pau, Tupai.

45 Tin-sand from do.

46 Wash-dirt from Kong Ju Ho Kongsi, Capt. Ah Kwi's mine at Tupai.

47 Tin-sand from Kong Jo Ho Kongsi, Capt Ah Kwi's mine at Tupai.

48 Wash-dirt from Capt. Ah Kwi's mine at Tupai.

49 Tin-sand from do.

50 Wash-dirt from Tie Li's mine at Tupai.

- 51 Tin-sand from do.

52 Wash-dirt from the Melbourne Tin Mining Co.'s mine at Tupai.

53 Tin-sand from the Melbourne Tin Mining Co.'s mine at Tupai.

54. Wash-dirt from Bun Lemg Kongsi, Capt. Ah Kwi's mine at Tupai.

55 Tin-sand from Bun Lemg Kongsi, Capt. Ah Kwi's mine at Tupai.

56 Wash-dirt from mine near Museum at Taiping.

57 Tin-sand from do.

58 Wash-dirt from mine at Taiping.

59 Tin-sand from do.

60 Wash-dirt from Khu On Keong's mine at Assam Kumbong.

61 Tin-sand from Khu On Keong's mine at Assam Kumbong.

62 Red wash-dirt from Tek Wah Kongsi at Assam Kumbong.

63 White wash-dirt from Tek Wah Kongsi at Assam Kumbong. 
Spec, 64 Tin-sand from Tek Wah Kongsi at Assam Kumbong.

65 Wash-dirt from Kwa Lu's mine at Assam Kumbong.

66 Tin-sand from

do.

67 Wash-dirt from Tye Sung Kongsi at Assam Kum= bong.

68 Tin-sand from Tye Sung Kongsi at Assam Kumbong.

69 Wash-dirt from Kwa Lu's mine at Assam Kumbong.

70 Tin-sand from Kwa Lu's mine at Assam Kumbong.

71 Wash-dirt from Kean Ju Kongsi at Assam Kumbong.

72 Tin-sand from Kean Ju Kongsiat Assam Kumbong.

73 Wash-dirt from Tie Li's mine at Kota.

74 Tin-sand from do.

75 Tin-sand from Changkat Batu, Trong.

76 Tin-sand from Swah Larra, Trong.

\section{DISTRICT OF KUALA KANGSAR, PERAK.}

Spec. 77 Auriferous tir-sand from Sungei Cherakoh. 78 Tin-sand from Sungei Kerbau, Sungei Plus.

79 Wash-dirt from Kong Yek's mine at Salak.

80 Tin-sand from do.

81 Coarse tin from do.

82 Wash-dirt from Lun Yeak's mine at Salak.

Depth of mine $9 \mathrm{ft}$., overburden $6 \mathrm{ft}$., washdirt $2 \mathrm{ft}$.

83 Tin-sand from Lun Yeak's mine at Salak.

84. Wash-dirt from Chan Fat's mine at Salak. Depth of mine $37 \mathrm{ft}$., overburden $32 \frac{1}{2} \mathrm{ft}$., wash-dirt $4 \frac{1}{2} \mathrm{ft}$.

85 Tin-sand from Chan Fat's mine at Salak.

86 Wash-dirt from Khu Cheat's mine at Salak. Depth of mine $5 \mathrm{ft}$., overburden $4 \mathrm{ft}$, wash-dirt $1 \mathrm{ft}$.

87 Tin-sand from Khu Cheat's mine a. Salak.

88 Wash-dirt from Thu Eng's mine at Biak. Depth of mine $24 \mathrm{ft}$., overburden $21 \mathrm{ft}$, wash-dirt $3 \mathrm{ft}$.

89 Tin-sand from Khu Eng's mine at Biak.

90 Wash-dirt from Kua Chew's mine at Biak. Depth of mine $13 \mathrm{ft}$., overburden $10 \mathrm{ft}$., wash-dirt $2 \frac{1}{2} \mathrm{ft}$.

91 Tin-sand from Kua Chew's mine at Biak.

92 Wash-dirt from Khu Eng's mine at Biak. Depth of mine $6 \mathrm{ft}$., overburden $3 \mathrm{ft}$., wash-dirt $3 \mathrm{ft}$. 93 Tin-sand from Khu Eng's mine at Biak.

94 Wash-dirt from Lun Yeak's mine at Biak. Depth of mine $12 \mathrm{ft}$., overburden $9 \mathrm{ft}$, wash-dirt $3 \mathrm{ft}$.

95 Tin-sand from Lun Yeak's mine at Biak. 
Spec. 96 Wash-dirt from Chan Fat's mine at Padang Balak. Depth of mine $13 \mathrm{ft}$, overburden $10 \mathrm{ft}$, washdirt $3 \mathrm{ft}$.

97 Tin-sand from Chan Fat's mine at Padang Balak. 98 Wash-dirt from Kong Ti Yun's mine at Prdang Balak. Depth of mine 14 ft., overburden $11 \mathrm{ft}$., wash-dirt $3 \mathrm{ft}$.

99 Tin-sand from Kong Ti Yun's mine at Padang Balak.

100 Wash-dirt from Mohammed Esah's mine at Neok Sepong. Depth of mine $9 \mathrm{ft}$, overburden $6 \mathrm{ft}$, wash-dirt $3 \mathrm{ft}$.

101 Tin-sand from Mohammed Esah's mine at Neok Sepong.

102 Wush-dirt from Ah Kai \& Co.'s mine at Plang. Depth of nime $12 \mathrm{ft}$, overburden $9 \mathrm{ft}$., washdirt $3 \mathrm{ft}$.

103 Tin-sand from Ah Kai \& Co.'s mine at Plang.

104. Wash-dirt from Ah Kai \& Co.'s mine at Plang. Depth of mine $7 \mathrm{ft}$, overburden $4 \mathrm{ft}$., washdirt $3 \mathrm{ft}$.

105 Tin-sand from Ah Kai \& Co.'s mine at Plang.

106 Wash-dirt from Itam Abu's mine at Plang. Depth of mine $7 \mathrm{ft}$, overburden $4 \mathrm{ft}$., wash-dirt $3 \mathrm{ft}$.

107 Tin-sand from Itam Abu's mine at Plang.

108 Wash-dirt from Raman Chetti's mine at Plang. Depth of mine $9 \mathrm{ft}$., overburden $6 \mathrm{ft}$, washdirt $3 \mathrm{ft}$.

109 Tin-sand from Raman Chetti's mine at Plang.

110 Wash-dirt from Lim Chong Molı's mine at Plang. Depth of mine $8 \mathrm{ft}$, overburden $5 \mathrm{ft}$, washdiret $3 \mathrm{ft}$.

111 Tin-sand from Lim Chong Moh's mine at Plang.

112 Wash-dirt from Itam Abu's mine at Plang. Depth of mine $8 \mathrm{ft}$, overburden $5 \mathrm{ft}$, wash-dirt $3 \mathrm{ft}$.

113 Tin-sand from Itam Abu's mine at Plang.

114. Wash-dirt from Ti Huck's mine at Lawit. Depth of mine $6 \mathrm{ft}$, overburden $3 \frac{1}{2} \mathrm{ft}$, wash-dirt $2 \frac{1}{2}$ $\mathrm{ft}$.

115 Tin-sand from Kum Ti Huck's mine at Lawit.

116 Wash-dirt from Toh Puan Halimah's mine at Lawit. Depth of mine $6 \mathrm{ft}$., overburden $3 \frac{1}{2} \mathrm{ft}$., wash-dirt $2 \frac{1}{2} \mathrm{ft}$.

117 Tin-sand from Toh Puan Halimah's mine at Lawit. 118 Wash-dirt from Kun Ti Huck's mine at Lawit. Depth of mine $6 \mathrm{ft}$, orerburden $4 \mathrm{ft}$., washdirt $2 \mathrm{ft}$.

119 Tin-sand from Kun Ti Huck's mine at Lawit.

120 Wash-dirt from Kun Ti Huck's mine at Lawit. Depth of mine $6 \mathrm{ft}$, overburden $3 \frac{1}{2} \mathrm{ft}$., washdirt $2 \frac{1}{2} \mathrm{ft}$.

121 Tin-sand from Kum Ti Huck's mine at Lawit. 
Spec. 122 Wash-dirt from Chun Zim's mine at Koh. Depth of mine $8 \mathrm{ft}$., overburden $5 \frac{1}{2} \mathrm{ft}$., wash-dirt $2 \frac{1}{2}$ ft.

123 Tin-sand from Chun Zim's mine at Koh.

124. Wash-dirt from Chun Zim's mine at Koh. Depth of mine $10 \mathrm{ft}$., overburden $8 \mathrm{ft}$., wash-dirt $2 \mathrm{ft}$.

125 Tin-sand from Chun Zim's mine at Koh.

126 Wash-dirt from Chun Zim's mine at Koh. Depth of mine $9 \mathrm{ft}$., overburden $7 \mathrm{ft}$., wash-dirt $2 \mathrm{ft}$.

127 Tin-sand from Chun Zim's mine at Koh.

128 Wash-dirt from Anjang Mohammed's mine at Sungei Sejuk. Depth of mine $7 \mathrm{ft}$., overburden $5 \mathrm{ft}$., wash-dirt $2 \mathrm{ft}$.

129 Auriferous tin-sand from Anjang Mohammed's mine at Sungei Sejuk.

130 Wash-dirt from Chan Fat's mine at Sungei Sejuk. Depth of mine $7 \mathrm{ft}$., overburden $5 \frac{1}{2} \mathrm{ft}$., washdirt $1 \frac{1}{2} \mathrm{ft}$.

131 Tin-sand from Chan Fat's mine at Sungei Sejuk. 132 Wash-dirt from Mat Sudin's mine at Troso. Depth of mine $12 \mathrm{ft}$., overburden $11 \mathrm{ft}$., wash-dirt $1 \mathrm{ft}$.

133 Auriferous tin-sand from Mat Sudin's mine at Troso.

134 Wash-dirt from Yong Yi's mine at Troso. Depth of mine $6 \mathrm{ft}$., overburden $3 \mathrm{ft}$., wash-dirt $3 \mathrm{ft}$.

135 Tin-sand from Yong Yi's mine at Troso.

136 Wash-dirt from Chan Kin Yong's mine at Lanor. Depth of mine $12 \mathrm{ft}$., overburden $11 \mathrm{ft}$., washdirt $1 \mathrm{ft}$.

137 Tin-sand from Chan Fin Yong's mine at Lanor.

138 Wash-dirt from Yun Chi and Gnor Kong's mine at Trol. Depth of mine $9 \mathrm{ft}$., overburden $7 \mathrm{ft}$., wash-dirt $2 \mathrm{ft}$.

139 Tin-sand from Yun Chi and Gnor Kong's mine at Trol.

KINTA DISTRICT, PERAK.

140 Wash-dirt from Chin Wun Yun's mine at Chendai Jelapang. Depth of mine $21 \mathrm{ft}$., overburden $19 \mathrm{ft}$., wash-dirt $3 \mathrm{ft}$.

141 Tin-sand from Chin Wun Yun's mine at Chendai Jelapang.

142 Wash-dirt from Malacca Mining Company's mine at Selibin, Ipoh. Depth of mine $31 \mathrm{ft}$., overburden $27 \mathrm{ft}$., wash-dirt $4 \mathrm{ft}$.

143 Tin-sand from Malacea Mining Company's mine at Selibin, Ipoh.

144 Wash-dirt from Klian Baru, Klaydong. This contains 8 per cent. of tin-sand.

145 Tin-sand from Klian Baru, Klaydong.

146 Wash-dirt from Che Noh's mine at Klaydong. 
Depth of mine $15 \mathrm{ft}$, overburden $9 \mathrm{ft}$, wash-dirt $6 \mathrm{ft}$.

Spec. 147 Tin-sand from Che Noh's mine at Klaydong, Ipoh.

148 Wash-dirt from Che Hussin's mine at Klian Baru, Ipoh. Depth of mine $24 \mathrm{ft}$, overburden $18 \mathrm{ft}$., wash-dirt $6 \mathrm{ft}$.

149 Tin-sand from Che Hussin's mine at Klian Baru, Ipoh.

150 Wash-dirt from Ugh Yi Tong's mine at Telok Baru, Ipoh. Depth of mine $30 \mathrm{ft}$, overburden $27 \mathrm{ft}$., wash-dirt $3 \mathrm{ft}$.

151 Tin-sand from Ugh Yi Tong's mine at Telok Ba= ru, Ipoh.

152 Wash-dirt from Toh Mudah Wahab's mine at Chendai, Tekka Menglembu. Depth of mine $30 \mathrm{ft}$., overburden $27 \mathrm{ft}$., wash-dirt $3 \mathrm{ft}$.

153 Tin-sand from Toh Muda Wahab's mine at Chendai, Tekka Menglembu.

154. Wash-dirt from Leong $\mathrm{Ki}$ and Shaik Yin Fuk's mine at Tekkc Menglembu. Depth of mine $25 \mathrm{ft}$, overburden $19 \mathrm{ft}$, wash-dirt $6 \mathrm{ft}$.

155 Tin-sand from Leong $\mathrm{Ki}$ and Shaik Yin Fuk's mine at Tekka Menglembu.

156 Wash-dirt from Ken Lam's mine at Ulu Menalai, Tekka Menglembu. Depth of mine $23 \mathrm{ft}$, overburden $17 \mathrm{ft}$., wash-dirt $6 \mathrm{ft}$.

157 Tin-sand from Ken Lam's mine at Ulu Menalai, Tekka Menglembu.

158 Tin-sand from Menglembu, near Ipoh.

159 Wash-dirt from Fu Chun's mine at Sorakai, Lahat.

Depth of mine $87 \mathrm{ft}$., overburden $20 \mathrm{ft}$., wash-dirt $67 \mathrm{ft}$.

160 Tin-sand from Fu Chun's mine at Sorakai, Lahat.

161 Wash-dirt from Chan On Siew's mine at Sorakai, Lahat. Depth of mine $33 \mathrm{ft}$, overburden $27 \mathrm{ft}$., wash-dirt $6 \mathrm{ft}$.

162 Tin-sand from Chan On Siew's mine at Sorakai, Laliat.

163 Wash-dirt from Low Kim's mine at Selinsin, Lahat. Deptl of mine 24 ft., overburden $19 \mathrm{ft}$., wash-dirt $5 \mathrm{ft}$.

164. Tin-sand from Low Kim's mine at Selinsin, Lahat.

165 Wash-dirt from Fu Chun's mine at Selinsin, Lahat.

Depth of mine $23 \mathrm{ft}$., overburden $8 \mathrm{ft}$., wash-dirt $15 \mathrm{ft}$.

166 Tin-sand from Fu Chun's mine at Selinsin, Lahat.

167 Wash-dirt from Chin Yeon Yun's mine at Selinsin,

Lahat. Depth of mine $24 \mathrm{ft}$., overburden 19 $\mathrm{ft}$, wash-dirt $5 \mathrm{ft}$.

168 Tin-sand from Chin Yeon Yun's mine at Selinsin, Lahat. 
Spec. 169 Wash-dirt from the French Mining Co.'s mine at Lahat.

170 Tin-sand from the French Mining Co.'s mine at Lahat.

171 Wash-dirt from the Freneh Mining Co.'s Mine de Jardin at Laliat. Depth of mine $16 \mathrm{ft}$,, overburden $14 \mathrm{ft}$., wash-dirt $2 \mathrm{ft}$.

172 Tin-sand from the French Mining Co.'s Mine de Jardin at Lahat.

173 Wash-dirt from the French Mining Co.'s Mine de Krani at laakat. Depth of mine $12 \mathrm{ft}$., overburden $11 \mathrm{ft}$, wash-dirt $1 \mathrm{ft}$.

174. Tin-sand from the French Mining Co.'s Mine de Krani at Lahat.

175 Wash-dirt from Papan.

176 Tin-sand from Papan.

177 Wash-dirt from Ho Chung's mine at Tampoi, Papan. Depth of mine $32 \mathrm{ft}$, overburden $12 \mathrm{ft}^{\prime}$., wash-dirt $20 \mathrm{ft}$.

178 Tin-sand froin Ho Chung's mine at Tampoi, Papan. 179 Wash-dirt from Ang Ho's mine at Papan. Depth of mine 14 ft., overburden $12 \mathrm{ft}$., wash-dirt $2 \mathrm{ft}$.

180 Tin-sand from Ang Ho's mine at Papan.

181 Wash-dirt from Ang Ho's mine at Johau, Papan. Depth of mine $14 \mathrm{ft}$., overburden $13 \mathrm{ft}$., washdirt $1 \mathrm{ft}$.

182 Tin-sand from Ang Ho's mine at Johau, Papan.

18.3 Wash-dirt from Chin Chong Si's mine at Lalang, Papan. Deptlı of mine $13 \mathrm{ft}$., overburden 11 ft., wash-dirt $2 \mathrm{ft}$.

184. Tin-sand from Chin Chong Si's mine at Lalang, Papan.

185 Wash-dirt from Chin Eng Ho's mine at Lalang, $\mathrm{Pa}$ pan. Depth of mine $18 \mathrm{ft}$., overburden $13 \mathrm{ft}$., wash-dirt $5 \mathrm{ft}$.

186 Tin-sand from Chin Eng Ho's mine at Lalang, Papan.

187 Wash-dirt from Ang Ho's mine at Kacha, Papan. Depth of mine $17 \mathrm{ft}$, overburden $17 \mathrm{ft}$., washdirt $1 \mathrm{ft}$.

188 Tin-sand from Ang Ho's mine at Kacha, Papan.

189 Wash-dirt from Ang Ho's mine at Kacha, Papan. Depth of mine $22 \mathrm{ft}$, , overburden $18 \mathrm{ft}$., washdirt $4 \mathrm{ft}$.

190 Tin-sand from Ang Ho's mine at Kacha, Papan.

191 Wash-dirt from Ang Ho's mine at Kacha, Papan.

Depth of mine $17 \mathrm{ft}$, overburden $16 \mathrm{ft}$., washdirt $1 \mathrm{ft}$.

192 Tin-sand from Ang Ho's mine at Kacha, Papan.

193 Wash-dirt from Dato' Panglima of Kinta's mine at Saiak, Batu Gajah. Depth of mine $7 \mathrm{ft}$., orerburden $5 \mathrm{ft}$, wash-dirt $2 \mathrm{ft}$. 
Spec. 194 Tin-sand from. Dato' Panglima of Kinta's mine at Saiak, Batu Gajah.

195 Wash-dirt fiom Koh Ki's mine at Teronoh, Batu Gajah. Depth of mine $19 \mathrm{ft}$., overburden 18 ft., wash-dirt $1 \mathrm{ft}$.

196 Tin-sand from Koh Ki's mine at Teronoh, Batu Gajah.

197 Wash-dirt from Li Nyuk's mine at Teronol, Batu Gajah. Depth of mine $15 \mathrm{ft}$., overburden 13 ft., wash-dirt $2 \mathrm{ft}$.

198 Tin-sand from Li Nyuk's mine at Teronoh, Batu Gajah.

199 Wash-dirt from Li Nyuk's mine at 'Teronoh, Batu Gajah. Depth of mine $16 \mathrm{ft}$, orerburden 12 ft., wash-dirt $4 \mathrm{ft}$.

200 Tin-sand from Li Nyuk's mine at Teronoh, Batu Gajah.

201 Wash-dirt from Shaik Yin Fuk's mine at Peti Baru, Batu Gajah. Depth of mine $20 \mathrm{ft}$., overburden $15 \mathrm{ft}$, wash-dirt $5 \mathrm{ft}$.

202 Tin-sand from Shaik Yin Fuk's mine at Peti Baru, Batı Grajah.

203 Wash-dirt from Chin Kim Fuk's mine at Teronoh, Batu Gajah. Depth of mine $19 \mathrm{ft}$, overburden $18 \mathrm{ft}$, wash-dirt $1 \mathrm{ft}$.

204 Tin-sand from Chin Kirn Fuk's mine at Teronoh, Batu Gajah.

205 Wash-dirt from Leong Ki's mine at Badak Mati, Batu Gajah. Depth of mine $11 \mathrm{ft.}$, overburden $8 \mathrm{ft}$., wash-dirt $3 \mathrm{ft}$.

206 Tin-sand from Leong Ki's mine at Badak Mati, Batu Gajah.

207 Wash-dirt from Si Puteh.

208 Tin-sand from do.

209 Wash-dirt from Tanjong Toh Along.

210 Tin-sand from do.

211 Red wash-dirt from near Police Station at Tan. jong Toh Along.

212 Wash-dirt from Tanjong Toh Along.

213 Tin-sand from do.

214 Wash-dirt from Ngah Durain's mine at Kantan, near Clummor. Depth of mine $20 \mathrm{ft}$., overburden $18 \mathrm{ft}$., wash-dirt $2 \mathrm{ft}$.

215 Tin-sand from Ngah Durain's mine at Kantan, rear Chumor.

216 Wash-dirt from Tan Ah Tin's mine at Tanjong Kambutan, Tambun. Depth of mine $31 \mathrm{ft}$., overburden $27 \mathrm{ft}$, wash-dirt $4 \mathrm{ft}$.

217 Tin-sand from Tan Ah Tin's mine at Tanjong Kambutan, Tambun.

218 Wash-dirt from Uda Manup's mine at Telok Tambun, Sungei Raia. Depth of mine $8 \mathrm{ft}$., orer- 
burden $6 \mathrm{ft}$., wash-dirt $2 \mathrm{ft}$.

Sepc. 219 Tin-sand from Uda Manap's mine at Telok Tambun, Sungei Raia.

220 Wash-dirt from the French Mining Co.'s mine at Gunong Pipit, Sungei Raia. Depth of mine $26 \mathrm{ft}$., overburden $21 \mathrm{ft}$., wash-dirt $5 \mathrm{ft}$.

221 Tin-sand from the French Mining Co.'s mine at Gunong Pipit, Sungei Raia.

222 Wash-dirt from Foh Hap's mine at Tekka, Sungei Raia. Depth of mine $31 \mathrm{ft}$., overburden $4 \mathrm{ft}$., wash-dirt $27 \mathrm{ft}$.

223 Tin-sand from Foh Hap's mine at Tekka, Sungei Raia.

224. Wash-dirt from Siew Keon at Sungei Raia Muda, Gopeng. Depth of mine $12 \frac{1}{2} \mathrm{ft}$., overburden, $5 \frac{1}{2} \mathrm{ft}$., wash-dirt $7 \mathrm{ft}$.

225 Tin-sand from Siew Keon at Sungei Raia Muda, Gopeng.

226 Wash-dirt from Wong Ki Tai's mine at Tanah Liat, Sungei Raia. Depth of mine $50 \mathrm{ft}$., overburden $46 \mathrm{ft}$., wash-dirt $4 \mathrm{ft}$.

227 Tin-sand from Wong Ki Tai's mine at Tanah Liat, Sungei Raia.

228 Wash-dirt from 'Towkay Baru's mine at Gopeng. Depth of mine $11 \frac{1}{2} \mathrm{ft}$., overburden $6 \frac{1}{2} \mathrm{ft}$., wash-dirt $5 \mathrm{ft}$.

229 Tin-sand from Towkay Baru's mine at Gopeng. Depth of mine $11 \frac{1}{2} \mathrm{ft}$., overburden $6 \frac{1}{2} \mathrm{ft}$, wash-dirt $5 \mathrm{ft}$.

230 Wash-dirt from the French Mining Co.'s mine at Klian Lalang, Gopeng. Depth of mine $15 \mathrm{ft}$, overburden $12 \mathrm{ft}$., wash-dirt $3 \mathrm{ft}$.

231 Tin-sand from the French Mining Co.'s mine at Klian Lalang, Gopeng.

232 Wash-dirt from the French Mining Co.'s mine at Klian Lalang, Gopeng. Depth of mine $15 \mathrm{ft}$., overburden $10 \frac{1}{2} \mathrm{ft}$., wash-dirt $4 \frac{1}{2} \mathrm{ft}$.

2:39 Tin-sand from the French Mining Co.'s mine at Klian Lalang, Gopeng.

234 Wash-dirt from the French Mining Co.'s mine at Sanglop Lalang, Gropeng. Depth of mine $10 \frac{1}{2}$ $\mathrm{ft}$., overburden $6 \mathrm{ft}$., wash-dirt $4 \frac{1}{2} \mathrm{ft}$.

235 Tin-sand from the French Mining Co.'s mine at Sanglop Lalang, Gopeng.

236 Wash-dirt from Sungei Siput, Kuala Diepong.

237 Tin-sand from Sungei Siput, Kuala Diepong.

238 Wash-dirt from foot of Gunong Siput, Kuala Diepong.

239 Wash-dirt from caves in a limestone hill called Gunong Siput, Kuala Diepong.

240 Wash-dirt from Ng Pat's mine at Pulau Gedong, Kampar. Depth of mine $30 \mathrm{ft}$, overburden 
$25 \mathrm{ft}$., wash-dirt $5 \mathrm{ft}$.

Spec. 241 Tin-sand from Ng Pat's mine at Pulau Gedong, Kampar.

\section{DISTRICT OF BATANG PADANG, PERAK.}

Spec. 242 Tin-sand from Cheang Ah Lin's mine at Chenderiang. Depth of mine $26 \mathrm{ft}$, overburden $18 \mathrm{ft}$, wash-dirt $8 \mathrm{ft}$.

243 Tin-sand from Chan Ah Kim's mine at Chenderiang. Depth of mine $19 \mathrm{ft}$., overburden $4 \mathrm{ft}$., washdirt $15 \mathrm{ft}$.

24.4 Tin-sand from Melbourne Mining Co.'s mine at Sungei Ulor, Chenderiang.

215 Tin-sand from: Melbourne Mining Co.'s mine at Sungei Ulor, Chenderiang.

246 Tin-sand from Malacca Mining' Co.'s mine at Chenderiang.

247 Tin-sand from Sungei Sengkang River, Tapah.

248 Auriferous tin-sand from Sungei Papan, near Tapah.

249 Auriferous tin-sand from Chu Ah Li's mine at Lankap. Depth of mine $12 \mathrm{ft}$, overburden 8 ft., wash-rlirt $4 \mathrm{ft}$.

250 Auriferous tin-sand from Kong Sung's mine at Paku. Depth of mine $15 \mathrm{ft}$., overburden 10 ft., wash-dirt $5 \mathrm{ft}$.

251 Auriferous tin-sand from Kong Sung's mine at Paku. Depth of mine $15 \mathrm{ft}$, , overburden 10 $\mathrm{ft}$, wash-dirt $5 \mathrm{ft}$.

252 Auriferous tin-sand from Hin Chit's mine at Paku. Depth of mine $13 \mathrm{ft}$, overburden $9 \mathrm{ft}$., washdirt $4 \mathrm{ft}$.

253 Auriferous tin-sand from Cheong Chin's mine at Lusun. Depth of mine $10 \mathrm{ft}$., overburden 6 ft., wash-dirt $4 \mathrm{ft}$.

254 Auriferous tin-sand from Klian Baru (unwashed). 255 Do. do. (washed).

256 Tin-sand from Fo Heng's mine at Katchu. Depth of mine $11 \mathrm{ft}$, overburden $7 \mathrm{ft}$., wash-dirt $4 \mathrm{ft}$.

257 Tin-sand from Chumor.

258 Coarse tin from Ah Fah's mine, Chumor Hill.

259 Tin-sand from Ah Fah's mine at Chumor Hill.

260 Tin-sand from Chumor.

261 Coarse tin from hill mines at Chumor.

262 Coarse tin from Ulu Slim.

263 Tin-sand from Sungei Kulit, Ulu Bernam.

264. Do. do.

265 Do. do.

266 Tin-sand from Ulu Bernam.

267 Tin-sand from Sungei Kulit, Ulu Bernam.

268

Do.

do. 
C L A Y S.

Spec. 1 China-clay, or Kaolin, as found in the tin mines at Assam Kumbang, Larut.

2 China-clay, partly cleaned, from Assam Kumbang, Larut.

3 Potters clay, used by the Malays, from Pulau Tiga, Lower Perak.

4. Tile-clay, from Chenderiang, Batang Padang.

\section{T I N S M E L T I N G.}

Spec. 1 Iron-sand from final washing of tin-sand.

2 Tin-sand ready for smelting.

3 Charcoal used in smelting the tin, Larut.

4. Tin slag from Chinese blast furnace, first melt, Larut.

5 Tin slag from Chinese blast furnace, second melt, Larut.

6 Tin slag from Chinese blast furnace, third melt, Larut.

7 Tin slag from Chinese blast furnace, fourth melt, Larut.

8 Tin slag from Chinese blast furmace, fifth melt, Larut.

9 Pounded slag from fifth melt, ready for washing, Larut.

10 Tin washed from pounded slag of fifth melt, Larut.

11 Refuse s?ag after washing, Larut.

12 Fire-clay used to build the Chinese blast furnace, Larut.

13 Coal used to smelt tin, Taipmg Smelting Works, Larut.

14. Anthracite, used as a flux in smelting tin, Taiping Smelting Works, Larut.

15 Front door tin slag from reverberatory furnace, coarsely pounded, Taiping Smelting Works, Larut.

16 Refuse tin slag from reverberatory furnace, Taiping Smelting Works, Larut.

17 Ingot of tin as exported, Taiping Smelting Works, Larut.

18 Grain tin, Taiping Smelting Works, Larut.

19 Ingot of Chinese smelted tin, as exported, Larut.

\section{MIN ERA L OGICAL SPECIMENS} FROM IM A L A C A.

Spec. 1 Quartz from Durian Tunggal.

2 Quartz from Bukit Panchor Rangè.

3 Quartz from Machap.

3a Rock crystal (Quartz) from Machap. 
4 Quartz from Bukit Tunggal, Alor Gajah.

5 Quartz from Jasin.

6 Quartz from different localities in Malacca.

7 Iron Stone from Durian Tunggal.

8 Iron Stone from Bukit Baru.

9 Iron Stone from Bertam.

10 Talcose Clay Slate.

11 Tin Ore from Malacca (Tan Hoon Guan).

$11 a$ Tin Dross from Kesang.

$11 b$ Tin Ore from do.

11c Tin Slfig from Malacea.

$11 d$ Tin Ore from Malacea (partially washed).

11 e Tin Ore from Malacea.

$11 f$ Tin Ore from do.

$11 \mathrm{~g}$ Tin Ore from do.

11 Amang.

12 Crystalline Quartz from Malacea (Tan Hoon Guan).

$12 a$ Crystalline Quartz from do. do.

$12 b$ Crystalline Quartz from do. do.

13 White Clay from Tin Mine, Malacca.

$13 a$ White Clay from do.

14. Grey Clay from Tin Mine, Malacea.

14a Grey Clay from do.

15 Plumbago, Tungay Baru.

16 Plumbago, Paku.

17 Bricks from Malacca.

\section{GEOLOGICAL SPECIMENS}

\section{FROM PERAK.}

Spec. 1 Granite from Taiping, Larut.

2 Granite from near Tapah, Batang Padang.

3 Granite from do.

4. Pink granite from do.

5 Granite from Upper Perak.

6 Micaceous granite from Upper Perak.

7 Gneiss from Upper Perak.

8 Felsite from Upper Perak.

9 Do. do.

10 Hard Black Schist from Blanda Mabok, Larut.

11 Black Schist from Plus River, Kuala Kangsar.

12 Black shale from Ulu Slim, Batang Padang.

13 Red schist from Larut.

14. Ferruginous clay rock from Larut.

15 Quartzite from Taiping, Larut.

16 Grey limestone from Upper Perak.

17 Limestone from Gunong Pondok, Kuala Kangsar.

$\begin{array}{llll}18 & \text { Do. } & \text { do. } & \text { do. } \\ 19 & \text { Do. } & \text { do. } & \text { do. } \\ 20 & \text { Do. } & \text { do. } & \text { do. }\end{array}$

? 21 Trap rock from Si Puteh, Kinta, 


\section{$5^{6}$ \\ ECONOMIC M I NERALS \\ F R O M PERAK. \\ ALUIMINIUIM.}

Spec. 1 Blue Corundum from near Tpoh, Kinta.

2 White Topaz from Chenderiang, Batang Padang.

\section{CARBON.}

Spec. 3 Plumbago or graphite, from near Tapah, Batang Padang.

\section{COPPER.}

Spec. 4. Copper ore from Selama Tin Mining Co.'s mine ac Tekka Menglembu, Kinta.

5 Copper ore from Ayer Daun Sang, near Lahat, Kinta.

6 Copper ore from Menglembu, near Ipoh, Kinta.

\section{IRON.}

Spec. 7 Brown iron ore from Chenderiang, Batang Padang. 8 Hematite from Upper Perak.

9 Wolfram (tungstate of iron and manganese) from Chumor, Batang Padang.

\section{LEAD.}

Spec. 10 Lead ore from Assam Kumbong, Larut. Contains 35 ozs. of silver per ton of ore.

11 Lead ore from Plang, Kuala Kangsar.

12 Lead ore from Talang near Lahat, Kinta.

\section{MANGANESE.}

Spec. 13 Manganese ore from Talang near Lahat, Kinta.

\section{SIIVER.}

Spec. 14. Silver-lead ore from Selama Tin Mining Co.'s mine at Blanda Mabok, Larut.

15 Silver-lead ore from Plumbe's lode, Selama Tir Mining Co.'s mine at Blanda Mabok, Larut.

TIN.

Spec. 16 Tin ore from Selama Tin Mining Co.'s mine at Blanda Mabok, Larut.

17 Tin ore from Plumbe's lode, Selama Tin Mining Co.'s mine at Blanda Mabok, Larut.

$18 \mathrm{Tin}^{-}$in micaceous granite from Waterfall Hill, Larut, 1,800 ft. elevation.

19 White tin ore from Kong Yek's mine at Salak, Kuala Kangsar.

20 Tin ore from Plang, Kuala Kangsar. 
Spec. 21 Tin ore from Selama Tin Mining Co.'s mine at Tekka Menglembu, Kinta.

22 Tin ore from Menglembu, Kinta.

23 Tin ore from Ayer Daun Sang near Lahat, Kinta.

\section{A L L U V I A G G L D M I N I N .}

spec. 1 Gold dust from Sungei Sejuk, Kuala Kangsar.

2 Three samples of alluvial gold from the Klian Baru mines, Batang Padang.

3 Gold dust from Sembiliang, Batang Padang.

4. Gold dust from Paku, Batang Padang.

\section{I S C E L L A N E O U S.}

Spec. 36-Yellow cocoons of silkworm (Bombyx sinensis) as exported from China for reeling, Larut.

$36 a$ White cenoons of silkworm (Bombyx sinensis) as exported to China for reeling, Larut.

37 Fish-maws from Mkan Poput Tamatu, Krian.

38 Fish-maws from Than Siakup, Krian.

39 Fish-maws from Ikan Kurau, Krian.

40 Fish-maws from Ikan Baguk, Krian.

41 Fish-maws from Ikan Temras, Krian.

42 Fish-maws from Ikan Pelautan, Krian.

43 Fish-maws from Ihan Selampai, Krian.

44. Fish-maws from Than Sludu, Krian.

45 Fish-maws from Ikan Goh, Krian.

46 Shark's fins from $Y u$ Kabai, Krian.

47 Shark's fins from Yu Kikier, Krian.

48 Shark's fins from Yu Kabong, Krian.

49 Shark's fins from the saw-fish, $Y u$ Parang, Krian.

Spec. 21 Fish-maws, Penang.

22 Fish leaf, Penang.

Turtle shell, Guthrie \& Co., Singapore.

Tortoise shell, Guthrie \& Co., Singapore.

1, 2, 3 Three qualities of edible nests of swiftlets, - . ? Sarawak, Borneo.

Bess' wax, Singapore.

Chinese pillow, Singapore.

Spee. 1 (14) Kélang, and model of deep sea fishing stake, Malacca.

2 (16) Teng Kála fishing trap used in paddy-fields, Malacca.

3 Fish water traps for fresh water fish (3 samples), Malacca.

4. (13) Flat bamboo trap, Malacca.

5 (15) Model of inshore fishing trap, Malacca.

6 (39) Fishing storing basket, Malacca. 
Spec. 7 (38) Slips of kabong palm used in making fishing stakes.

8 (42) Tikar tidor, sleeping mat, Malacca.

99 a Clay pots, Malacca.

10 (40) Paddy stalk brooms.

Spec. 269 Tin ore, from Perak.

270 Tin ore, from Menglembu, Kinta, Perak.

271 Tin ore, from Ayer Daun Sang, near Lahat, Kinta.

272 Tin ore, from Plumber's Lode, Selama Tin Mining Co's. mine at Blanda Mabok, Larut.

273 Tin ore, from Selama Tin Mining Co., Tekka Menglembu, Kinta.

274 Copper ore, from Menglembu, near Ipoh, Kinta.

$272 a$ Same as 272.

275 Lead ore, from Assam Kumbang, Larut. Contains 35 ounces of silver to the ton of ore.

276 Hematite, Upper Perak.

277 Tin in micaceous granite, Waterfall Hill, Larut, $1,800 \mathrm{ft}$. elevation.

278 Limestone, Gunong Pondok, Kuala Kangsar.

279 Ganite, near Tapah, Batang Padang.

280 Tin ore, Plang, Kuala Kangsar.

281 Blue corundum, near Ipoh, Kinta.

282 Manganese ore, Talang, near Lahat, Kinta, Batang Padang.

28.3 Wolfram (lungetate of iron and manganese), Chumor.

284. Limestone, Gunong Pondok, Kuala Kangsar.

285 Quartzite, Taiping, Larut.

286 Limestone, Gunong Pondok, Kuala Kangsar.

287 Trap Rock, Si Puteh, Kinta.

288 Felsite, Upper Perak.

289 Pink granite, near Tapah, Batang Padang.

290 Copper ore, from Ayer Daun Sang, West Lahat Kinta.

291 Lead ore, Talang, near Lahat, Kinta.

292 Limestone, Gunong Pondok, Kuala Kangsar.

293 Granite, Upper Perak:

$\approx 9+$ Granite, Taiping, Larut.

295 Felsite, Upper Perak.

296 Hard black schist, Blanda Mabok, Larut.

297 Gery limestone, Upper Perak.

298 Silver lead ore, from Selama Tin Mining Co.

299 Red schist, Larnt.

300 Lead ore, from Plang, Kuala Kangsar.

301 Black shale, Ulu Slim, Batang Padang.

302 Black schist, Plus River, Kuala Kangsar.

303 White tin ore, Kong Gek mine, Salak, Kuala Kangsar.

304 White topaz, Chenderiang, Batang Padang. 
Spec. 305 Tin ore, from Plumber's Lode, Selangor Tin Mining Co., Batang Malaka, Larut.

306 Plumbago, near Tapah, Batang Padang.

307 Copper ore, Selama Tin Mining Co., Tekla Menglembu, Kinta.

308 Gneiss, Upper Perak.

309 Brown iron ore, Chenderiang, Batang Padang.

310 Micaceous granite, Upper Perak.

311 Silver lead ore, Plumber's Lode, Selangor Tin Mining Co., Batang Malaka, Larut.

312 Ingot of tin, as exported, Larut.

313 Ingot of tin, as exported Taiping.

314. Ferruginous clay rock, Larut.

Tin ore, in block, from Pataling, Selangor.

Tin-sand, coarse, from Sungei Besi.

Wash-dirt, Batu, Selangor.

Tin-sand Batu, Selangor.

Tin-sand, Pataling.

Wash-dirt, Pataling.

Tin ore, Sungei Besi.

Tin ore, Pataling. 
Turbes one tobeca

Dexpesentint

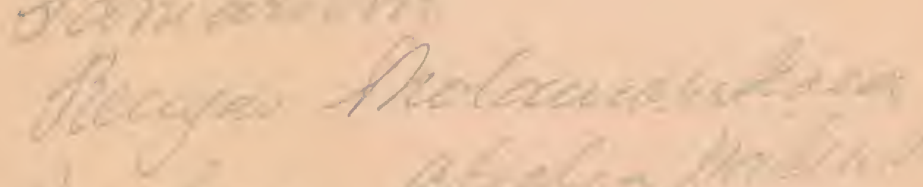

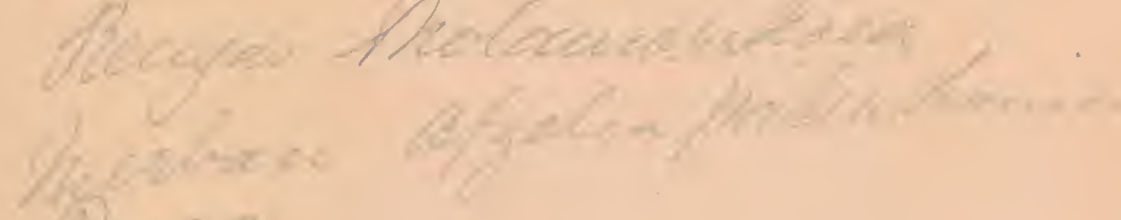

Oporar

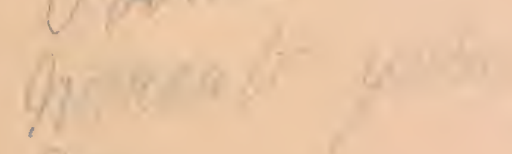

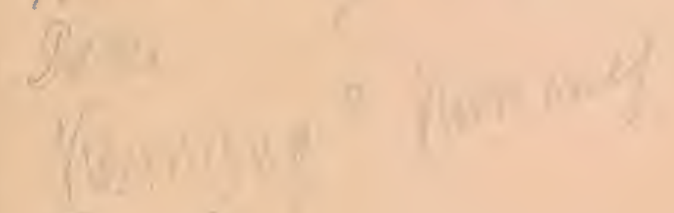

Develit 

